\title{
Performance of Existing Modernist Buildings in Barcelona ${ }^{1}$
}

\author{
Rosangel Moreno González; ; Jesús M. Bairán² \\ ${ }^{1} \mathrm{PhD}$. Civil Engineer, Researcher, (Corresponding author). E-mail: mgrosangel@ciccp.es \\ ${ }^{2}$ PhD. Civil Engineer, Assoc. Professor. E-mail: jesus.miguel.bairan@upc.edu \\ Dept. of Construction Engineering, Universitat Politecnica de Catalunya, Campus \\ Nord, C/Jordi Girona 1-3, Mod. C-1, 201-b, 08034, Barcelona, Spain.
}

Abstract: Seismic vulnerability of a set of unreinforced masonry aggregated buildings of more than 70 years old, located in Barcelona (Spain) is investigated. Four different model buildings are studied: they consist of three isolated buildings and one aggregated system, which are representative of most typical structural configurations used in the city. The aggregated building blocks are built individually without any gaps between them, thus interacting under lateral loads. The seismic hazard is described by the elastic response spectrum defined in Eurocode-8. Capacity curves are obtained using a nonlinear static analysis procedure; they are used to obtain the displacement based fragility functions, the performance point, the probability damage matrices and the mean damage factor, corresponding to the specified seismic action. In spite of the low-to-moderate seismic hazard in the region the results show a high percentage of buildings having moderate and severe damage, depending on the soil type, and their brittle performance makes them seismically vulnerable. The overall behaviour of the aggregate system is controlled by the fragility of the two corner buildings.

CE Database subject headings: Masonry; Seismic analysis; Residential buildings; Static structural analysis; Limit states.

Author Keywords: Aggregated buildings; Vulnerability; Fragility functions; Unreinforced masonry; Seismic damage.

\footnotetext{
${ }^{1}$ Moreno-González R, Bairán JM (2015), "Performance of existing modernist buildings in Barcelona", ASCE Journal of Constructed Facilities, Vol 29, № 4, 10.1061/(ASCE)CF.1943-5509.0000501, 04014091.
} 


\section{Introduction}

Most of the losses due to earthquakes are caused by the bad seismic behaviour of structures; the high concentration of population, buildings and infrastructures increase the seismic risk in urban areas. Furthermore, advances in structural design are applied to new structures and, to a smaller extent, to the rehabilitation of existing ones. Nevertheless, there exist more old structures than newly constructed ones. So, it is necessary to incorporate a methodology to analyse the vulnerability and seismic damage of existing buildings in order to reduce risks in urban areas and authorities planning. The key element in the vulnerability modelling is the capacity of building to sustain loads and displacements due to seismic shaking.

In the past, many existing masonry buildings were constructed following the rule of thumb, learning from experience of previous similar structures. Hence, they were constructed by refining the proportions of structural elements by a deep perception of their structural behaviour. This trial and error process took into consideration only the gravity loads, mainly dead loads (Lagomarsino 2006). It is important to evaluate the fragility of these structures in order to have an estimation of the expected damage in front of the probable seismic events. Some researchers have studied the unreinforced masonry, buildings, churches and other historical constructions (Shahzada et al. 2012; Qaisar and Akhtar 2012; Frumento et al. 2006; Betti and Vignoli 2008 and 2011; etc). The behaviour of these structures depends on their particular construction techniques and the materials used.

In this work, a method based on the capacity spectrum is used to characterize the vulnerability and the expected damage of the Unreinforced Masonry Buildings (UMB) of the city of Barcelona, Spain. Capacity spectrum method (ATC-40 1996; Freeman 1998; HAZUS-SR2-99 1999; Calvi 1999; Fajfar 2000; Milutinovic and Trendafiloski 
2003; Mouroux and Le Brun 2006; Faccioli 2006) is used to estimate the capacity spectrum and from this the degree of damage of the building.

Barcelona is the second largest city of Spain. The city is divided into 10 districts where the district Eixample is the second oldest of the city, which was designed at the end of the XIX century and the beginning of XX, it has a large representation of the Spanish modern-style architecture (art noveau) and also a reference of the modern urbanism.

Eixample's structures can be described in 4 periods: pre-modernism (18601900), modernism (1890-1910) and post-modernism (1910-1936); in these first 3 periods the predominant construction system is masonry. The last period started in the 60 's decade when reinforced concrete, as construction material in buildings, began to be important, leading to the beginning of contemporary architecture (Paricio 2001).

Most buildings in the Eixample district are not isolated in the lateral response, but they are part of aggregate buildings systems forming blocks. In these systems, it is possible to distinguish two main types of buildings, one corresponding to the lines buildings along of the street with a rectangular shape, and the other corresponding to the corner buildings in the intersection of two streets with a pentagonal shape. This scheme is repeated forming almost symmetric squared blocks with a total of 520 blocks and an average of 25 buildings per block.

According to Risk-UE European project (Milutinovic and Trendafiloski 2003) the city of Barcelona has a total of 86,744 buildings, among which, $75,932(87 \%)$ are residential buildings (housings) and the main typologies are unreinforced masonry (77\%) and reinforced concrete $(18 \%)$ buildings. The most common building type is unreinforced masonry with the following distribution of floors systems: timber $(32 \%)$, masonry vaults (18\%), steel or timber beams with masonry vaults $(26 \%)$ and reinforced 
concrete beams and masonry vaults (1\%). Steel buildings either moment resisting frames or braced frames and frames with unreinforced masonry infill walls are only $3 \%$ of the total. Composite concrete-steel systems are $2 \%$ of the total (Lungu et al. 2001).

Most of these masonry buildings have an average age of 80 years and they have been designed and built without considering any seismic resistant criterion. Figure 1 shows the age distribution of the buildings as a function of the construction periods. It can be seen that almost $80 \%$ of the buildings stock of Barcelona were built prior to the first seismic Spanish code of 1968, as was pointed out in Barbat et al. (2006).

The main objective of this paper is to present the developed procedure and results estimated of the seismic vulnerability and damage of existing modernist unreinforced masonry buildings, isolated and aggregated, located in the different soil types of the city. The seismic damage analysis of one side of squared blocks is considered with the goal of obtaining the damage probability matrices for Masonry Aggregated System buildingS (MASS), which are typical of one of the most emblematic districts of the city of Barcelona and with an important historic and architectonic value.

The buildings models used in this study were constructed based on detailed data obtained from drawings and actual reports regarding existing structures, such as, pathology studies carried out on many of these buildings (Mari et al. 2003). These data allowed defining the mechanical properties, calculating the capacity curves, displacement based fragility functions and damage probability matrices, obtaining results for isolated buildings and the aggregated system, which showed a high seismic vulnerability and an important seismic damage for the seismic action considered for Barcelona. 


\section{Seismic hazard}

Barcelona is situated on the northeast Mediterranean coast and it is delimited by Collserola Mountain, Besòs and Llobregat rivers and by the Mediterranean Sea. The city has a low to moderate seismicity and weak tectonic motions. The seismic action is defined according to Spanish normative (NCSE-02 2002) in terms of 5\% damped elastic response spectrum, where the basic seismic acceleration is $0.04 \mathrm{~g}$. The shape of the response spectra were related to each soil class as in Eurocode 8 (CEN 2004), four types of soil: A, B, C and D were considered. Soil A corresponds to hard soils and D is soft soils, while $\mathrm{C}$ and $\mathrm{B}$ are made of intermediate soils.

These four soil types (A, B, C, D) are compatible with the main geological units of the city, according to the seismic microzonation of Barcelona (Cid et al. 2001), soil type A represents the rock zone, type D is located near to the deltas of the rivers and to the marine front, while soil types $\mathrm{B}$ and $\mathrm{C}$ are similar in characteristic and they are found between soft soils (D) and hard soils (A), respectively.

The elastic response spectrum is defined by 4 branches: very low period branch (from peak ground acceleration to the constant acceleration branch), constant acceleration, constant velocity and constant displacement. These branches are separated by 3 "corner" periods $\mathrm{Tb}, \mathrm{Tc}, \mathrm{Td}$. The parameters considered for the studied cases are given in Table 1 and Figure 2 shows the corresponding elastic response spectra, see Eurocode 8 (CEN 2004).

\section{Methods and material}

\section{Description of the structural models}

Very sophisticated finite element models or extremely simplified methods are frequently used for the analysis of masonry buildings. In this work, an intermediate approach, based on a macroelement strategy, is used for modelling the in-plane 
behaviour of masonry walls in the buildings (Gambarotta and Lagomarsino 1993, 1997). This approach allows accurate simulation of the non-linear response of the complete building without heavy computational demand. The model was implanted in the TreMURI software, developed at Università degli Studi di Genova (Genoa, Italy) by Galasco et al. (2002). TreMURI program allows 3D non-linear static and dynamic analysis of masonry structures combined with elements of other materials such as, i.e. wood, iron or reinforced concrete.

TreMURI program allows performing structural analyses with 3D models in taking into account the in-plane flexibility of the floor (S.T.A. Data 3Muri General Description 2013). Each macroelement has six degrees of freedom and allows representing the two main in-plane failure modes of masonry: bending-rocking and shear-sliding (with friction) mechanisms (see Figure 3), on the basis of mechanical assumption. The out-of-plane response was not included in the analysis. The effect of local out-of-plane bending of the floors is not considered to be significant in the global lateral response (Lagomarsino et al. 2008).

A masonry panel is represented by a non-linear macroelement model. Figure 4 shows the three substructures in which a macroelement is divided: two layers, inferior (1) and superior (3), in which the bending and axial effects are concentred, and the central part (2) which suffers shear deformations and does not have axial or bending deformations. A complete 2D kinematic model should take into account the 3 degrees of freedom for each node $i$ and $j$ on the extremities: where, $w_{i, j}$ is the axial displacement, $u_{i, j}$ is the horizontal displacement and $\varphi_{i, j}$ is the rotation. In the central zone there are 2 degrees of freedom: $\delta$ is the axial displacement and $\phi$ is the rotation, see Figure 4, (Penna et al. 2009). 
In this model, masonry softening is controlled by means of a shear-sliding damage evolution process that produces a deterioration of material's strength and stiffness (Penna 2002; Galasco et al. 2004). This model was validated after an experimental campaign on a full-scale masonry building carried out in the Laboratory of the University of Pavia (Magenes et al. 1995; Magenes and Calvi 1997) as presented in Penna et al. (2009).

\section{Construction system of the Eixample district}

The construction system of the Eixample district is based in a more or less repetitive scheme with certain variations, forming a vernacular construction. Typical blocks are almost symmetrically square sizing about $113.3 \mathrm{~m} \times 113.3 \mathrm{~m}$, they are perfectly aligned and they are bevelled in their vertices by edges of about $20 \mathrm{~m}$ (with $45^{\circ}$ angled corner of each block). Figure 5 shows typical blocks of the Eixample district.

UMB is based on brick material, slab type and number of floors. A high percentage of the existent buildings have between 6 to 8 stories. In this construction technique, buildings were built individually but without any gap between them. In most cases, they are built one next to each other without any clearance, forming aggregate building blocks which interact under lateral loads. In other cases, buildings may share the same sidewall. Systematically, some of these buildings have two soft stories due to existence of garages, stores and other commercial facilities which may require different story height in the first floors.

UMB are rectangular in plan; usually, in the central part of the buildings there exist one or more cores, partially enclosed by brick walls of $10 \mathrm{~cm}$ thick, formed around stair walls or courtyards. The distribution of the bearing walls respond to three fundamental structural patterns: 1- Façades walls (street and backyard block) work as bearing walls together with a set of load interior walls, parallel to them. 2- In the case of 
narrow buildings, the floor is formed in transverse direction acting the secondary walls as bearing walls. 3 - In the case of corner buildings, the plan geometry is trapezoidal, the façades of the street and courtyard act as bearing walls, there is an interior second load wall parallel to the street façade and other interior walls are used as bearing elements (Mari et al. 2003). Figure 6 shows façades walls and floor plan, these figures are taken from original drawings.

The floors are unidirectional loading system, either made of timber, steel or precast concrete beams with small ceramics or mortar vaults in between, depending on the construction date. They show low stiffness both to bending moments and to axial forces, typical details are showed in Figure 7.

\section{Building models}

In a first step isolated building analyses were conducted on three structures which are representative of a wide number of existing residential buildings. These structures were analysed along their two main directions: $Y$-direction (perpendicular to the street) and $X$-direction (parallel to the street). In a second step, the structures were combined in order to form a MASS which is analysed in $X$-direction (parallel to the street). Figure 8 shows an example of a typical block and the MASS here studied; consisting in one of the four lines of the block and the no-clearance joint between adjacent buildings.

The three buildings considered consist on a corner building (CB), a narrow (NB) and wide (WB) interior buildings. To model a whole side of the block seven individual buildings were combined from the previous mentioned set, forming the MASS model as follows: $C B_{1}+N B_{1}+W B_{1}+N B_{2}+W B_{2}+N B_{3}+C B_{2}$, see Figure 8 . In this model the structures are considered attached without possibility of pounding effect. 
The CB model has a complex trapezoidal in plan shape; the walls are aligned in three different directions, coincident with the street intersection. The walls of the front and back façades have a thickness of $0.40 \mathrm{~m}$ and $0.30 \mathrm{~m}$, respectively, while the interior walls are $0.15 \mathrm{~m}$ thick. The interior bearing system of the first two stories consists on steel beams and columns, which support interior bearing walls of the upper stories. Figure 9 shows the plan, macroelement model of one of the walls and a 3D view of the model.

In the NB model the main façade wall has a maximum thickness of $0.50 \mathrm{~m}$ and back façade has $0.45 \mathrm{~m}$ of thickness in the base story and $0.40 \mathrm{~m}$ and $0.30 \mathrm{~m}$ of thickness in all upper stories. Lateral walls are $0.30 \mathrm{~m}$ thick in the base floor and $0.15 \mathrm{~m}$ in upper stories, while interior walls have a thickness of $0.15 \mathrm{~m}$ in all stories. Figure 10 shows a 3D view of the building modelled with TreMURI program and the main façade wall.

The façade of the WB model has a thickness of $0.30 \mathrm{~m}$, all other walls are $0.15 \mathrm{~m}$ thick. In the base and first stories there are steel beams and columns, which support the weight of the upper interior walls. Figure 10, also shows a 3D view of the model and the main façade. Figure 11 shows the plans of the two interior buildings (NB and WB).

Figure 8 shows the modelled MASS assembly. In all previous cases, the floor system is made of timber with the structural configuration described in Figure 7 (slab 2). Therefore, it was necessary to explicitly model the in-plane stiffness of the floor deck.

Material properties were considered based on available pathological studies carried out on similar structures (Alegre 2002) and previous characterization studies conducted on this construction typology (Yépez 1996; Tomazevic 1999). Moreno (2006) describes the main characteristics and properties of the materials used in the construction of UMB, which are masonry panel and floors. The same author reviews the 
masonry strength to shear, to tension and to compression as well as its behaviour under cyclic and dynamic loads. The mechanical properties used in this study have been adjusted based in technical reports of restoration of unreinforced buildings of Barcelona. For the masonry panels elements the following mechanical properties are used: $f_{m k}=4.0 \mathrm{Nmm}^{-2}$ (compression strength), $\tau_{k}=0.12 \mathrm{~N} \mathrm{~mm}^{-2}$ (shear strength), $E=1800 \mathrm{~N} \mathrm{~mm}^{-2}$ (elastic modulus), $G=300 \mathrm{~N} \mathrm{~mm}^{-2}$ (shear modulus), $\gamma=18.0 \mathrm{kN} \mathrm{m}^{-3}$ (specific weight). The nonlinear response of the masonry walls is described by generalized constitutive relationship between degrees of freedom and internal forces of the macroelements, see Brencich and Lagomarsino (1998) and Penna (2002).

The mechanical properties of the timber floor elements, modelled as orthotropic membrane finite elements, are: $E_{1}=4000 \mathrm{~N} \mathrm{~mm}^{-2}$ (elastic modulus parallel to the fibre), $E_{2}=40 \mathrm{~N} \mathrm{~mm}^{-2}$ (elastic modulus perpendicular to the fibre) and $q=5.0 \mathrm{kN} \mathrm{m}^{-2}$ (load). The steel profiles elements are $H E B-200$ for the columns and $I P N-360$ for the beams, and their elastic modulus is $E_{s}=2.1 \mathrm{E} 5 \mathrm{~N} \mathrm{~mm}^{-2}$.

\section{Analysis and results}

Two studies are carried out to analyse the seismic performance of modernist buildings in Barcelona: firstly, 3 type models of the masonry existing buildings ( $\mathrm{CB}, \mathrm{NB}, \mathrm{WB})$ are assessed as isolated buildings, this analysis was focused in the direction of interest of the study, i.e. perpendicular to the street ( $Y$-direction). On the other hand, the response of these buildings in $X$-direction (parallel to the street) was combined to evaluate, simplified form, the performance of masonry aggregated system buildings (MASS) working as a single building block.

\section{Modal response analysis}

A modal analysis was carried out to obtain the different modes of vibration of the buildings and their modal frequencies. Table 2 shows the basic modal properties of 
the buildings, Modal Participation Factor (MPF, $I$ ) and the vibration natural period $(T)$, of the main modes obtained in each horizontal direction, parallel to the street $(X)$ and orthogonal to the street $(Y)$. A total of 11 vibration modes were considered until the sum of effective modal mass reaches a minimum of $90 \%$ of the total mass in each direction, as required in CEN (2004).

Figure 12 shows the first three vibration modes of NB building. It is noticed that the translational modes are uncoupled from the torsional ones and are controlled by one mode. For the horizontal pushover analyses the control node has been located in the centre of masses of the top story.

In the $X$-direction, in spite of the different in-plan geometry of the buildings, similar vibration modes were obtained for all of them, see Table 2, due to the fact that the three buildings have similar heights and construction system as well as mechanical properties. Therefore, a plausible approximation of the MASS response can be obtained by superposition of the response of each building for the above mentioned combination $\left(C B_{1}+N B_{1}+W B_{1}+N B_{2}+W B_{2}+N B_{3}+C B_{2}\right)$, see Figures 8; that is to say, from SDOF the capacity spectra were obtained and superimposing the response (in $X$-direction) of each building, the capacity spectrum of MASS was estimated. The period of vibration and MPF for the equivalent SDOF of MASS model were obtained as $T_{x}{ }^{*}=0.818 \mathrm{~s}$ and $\Gamma_{x}=$ 1.451, see Table 2. These values of the vibration period are in consonance with experimental observations on similar constructions (Bal et al. 2008) where the type of floor and bricks have a high influence.

\section{Seismic behaviour assessment}

The seismic vulnerability analysis was inspired by the simplified methodology proposed in the Risk-UE project (Milutinovic and Trendafiloski 2003) and this is used to estimate the seismic damage of unreinforced masonry buildings. This method is 
based in the Capacity Spectrum Method (ATC-40 1996) which consists on calculating the capacity spectrum of the structure after a pushover analysis. Furthermore, to determine the probability of damage state displacement based fragility functions are built based on the bilinear capacity spectrum. Finally, damage probability matrices are obtained by means of the displacement based fragility functions and the maximum displacement in the building due to the seismic demand, this displacement is the performance point. The damage probability matrices show the probability of occurrence of each damage state, which can occur at a given location. Damage probability matrices can be useful to evaluate the seismic risk of buildings, to construct seismic damage scenarios, to simulate earthquake risk scenarios; however, the latter are not the objectives of this work.

\section{Vulnerability modelling}

The seismic performance of the buildings can be characterized by its capacity spectrum obtained by means of a pushover analysis, which allows obtaining the base shear versus top displacement curve. This curve is a relationship between the lateral load capacity and the top displacement. Pushover analysis was carried out under conditions of constant gravity loads and monotonically increasing lateral loads. The distribution of the lateral loads applied is consistent with the fundamental mode of vibration, which is consistent with the European code (CEN 2004). The control displacement was monitored at the centre of mass of the top story.

After a suitable change of variables, the pushover curve is transformed into the capacity spectrum in which vertical axis represent the spectral acceleration $(S a)$ and the horizontal axis represent the spectral displacement $(S d)$. Capacity spectrum is represented in bilinear form to build the fragility functions, which characterize the damage of a building for any seismic action (Moreno and Bairán 2013). 
Fragility functions are the graphical representation of the cumulative probability density function of reaching or exceeding a certain damage limit state for a giving value of a parameter that represents the intensity of the seismic action. In this method, the chosen intensity parameter was the spectral displacement. Displacement based fragility functions are defined according to Equation (1) under the assumption that they follow a log-normal probability distribution (HAZUS-SR2-99 1999; Milutinovic and Trendafiloski 2003),

$$
P(D S / S D)=\Phi \cdot\left[\frac{1}{\beta_{D S}} \cdot \ln \left(\frac{S d}{\overline{S d_{D S}}}\right)\right]
$$

where, $\overline{S d_{D S}}$ is the mean spectral displacement for which the probability of having a determined damage state $(D S)$ is $50 \%$, also known as threshold spectral displacement. $\beta_{D S}$ is the coefficient of variation of the natural logarithm of the spectral displacement for the damage limit state under consideration $D S . \Phi$ is the normal cumulative distribution function and $S d$ is the spectral displacement. Subscript $D S$ indicates the considered damage state and may take the following values: 1 for slight damage, 2 for moderate damage, 3 for extensive (severe) damage and 4 for collapse damage. These damage states have the same meaning as in the references Grünthal (1998) and Barbat et al. (2006).

Each displacement based fragility function requires the definition of the damage threshold $\left(\overline{S d_{D S}}\right)$ of the specific damage state and the variability associated with it, $\beta_{D S .}$ The determination of the damage thresholds are defined in terms of the yielding $\left(S d_{y}\right)$ and ultimate $\left(S d_{u}\right)$ displacements by using the following conditions: $\overline{S d_{1}}=0.7 \cdot S d_{y}$ for slight damage, $\overline{S d_{2}}=S d_{y}$ for moderate damage, $\overline{S d_{3}}=S d_{y}+0.25 \cdot\left(S d_{u}-S d_{y}\right)$ for extensive damage and $\overline{S d_{4}}=S d u$ for collapse damage (Barbat et al. 2006). In general, capacity 
spectrum is a non-linear curve without a clear yielding point; therefore, an objective methodology is needed to define the yielding displacement. This task is done by fitting a bilinear curve to the non-linear capacity spectrum having the same dissipative energy.

Figure 13 shows the capacity curves obtained (in $Y$-direction) from pushover analysis and the corresponding bilinear representation for $\mathrm{CB}, \mathrm{NB}$ and $\mathrm{WB}$ models, furthermore, it shows the capacity curve for MASS (in $X$-direction).

Table 3 shows the yield and ultimate capacity points defining the bilinear capacity spectra of CB, NB, WB and MASS. $S a_{y}$ and $S a_{u}$ are the ordinates of $S d_{y}$ and $S d_{u}$, respectively; these parameters are in spectral coordinates. The points defined in this table are used to define the damage state threshold for the displacement based fragility functions, these functions are named fragility curves, too.

In the Risk-UE project (Milutinovic and Trendafiloski 2003) the coefficients of deviation $\left(\beta_{D S}\right)$ used for Barcelona are defined assuming that the expected seismic damage in buildings follows a binomial probability distribution. It is assumed that at the $\overline{S d_{D S}}$ threshold the probability of this damage state is $50 \%$ and then the remaining damage states are estimated by integrating probability density function. Finally, the fragility curve equation is fitted to the obtained points by means of a least squares regression (Moreno 2006). Table 4 shows the corresponding parameters to define the fragility curves. Figure 14 shows the fragility curves obtained for $\mathrm{CB}, \mathrm{NB}$ and $\mathrm{WB}$ and Figure 15 shows the corresponding to MASS.

\section{Seismic performance}

The seismic behaviour of a building can be quantified by means of its maximum expected response, which is obtained from of capacity and demand spectra and it is represented by means of the performance point $\left(S d_{P P}\right)$. 
There are different methods to obtain the demand spectrum and the performance point. In order to avoid costly computational iterations, the method described in annex B of the Eurocode 8 (CEN 2004) is followed here to determine the performance point.

Table 5 shows the corresponding $S d_{P P}$ for the buildings $\mathrm{CB}, \mathrm{NB}, \mathrm{WB}$ and for the MASS, located in the different soil types existing in Barcelona zoning.

\section{Damage probability matrices}

The damage probability matrices (DPM) for a given seismic scenario and for one building is obtained by entering with the performance point (defined in Table 5) into the corresponding displacement based fragility curves (Figures 14 and 15), in order to obtain the probability of having a damage less or equal to the threshold. Therefore, the probability of having a damage state $i$ for the spectral displacement $S d_{P P}$ is given by the difference of the probability of the $i$ damage threshold and the probability of the $i+1$ damage threshold, Equation (2).

$$
P\left(D S_{i} / S d_{P P}\right)=P\left(D S_{i} / S d_{P P}\right)-P\left(D S_{i+1} / S d_{P P}\right)
$$

$P\left(D S_{i} / S d_{P P}\right)$ is the probability of occurrence of damage state $D S_{i}$ when the structure has a spectral displacement $S d_{P P}$.

Table 6 shows the DPM for each building localized in different zones defined by the soils type under earthquakes corresponding to the acceleration of Barcelona $(0.04 \mathrm{~g})$.

\section{Expected seismic damage}

To quantify the results and to obtain the expected seismic damage, in a simplified manner, a weighted mean damage parameter $\left(D_{M}\right)$ is used, which is an estimation of the most likely damage state of the structure and it can be calculated starting from damage probability matrices as, Equation (3): 


$$
D_{M}=\sum_{i=0}^{i=4} i \cdot P(i)
$$

where, $i$ corresponds to each damage state considered and $P(i)$ is the probability of occurrence of the damage state $i$. Index $i$ takes the values $0,1,2,3$ and 4 for the damage states: no damage, slight, moderate, severe and collapse, respectively. The more probable damage states is defined as: no damage $0 \leq D_{M}<0.5$; Slight $0.5 \leq D_{M}<1.5$; Moderate 1.5 $\leq D_{M}<2.5$; Severe 2.5 $\leq D_{M}<3.5$; Collapse $3.5 \leq D_{M} \leq 4.0$ (Moreno and Bairan 2013).

Table 7 shows the mean damage parameter obtained to each building and to each soil type. This factor will be used to comment the results of the analysis.

\section{Discussions}

In direction orthogonal to the street WB shows higher ductility (6.72) than NB (4.73) and $\mathrm{CB}$ (4.63) buildings with a slightly softening behaviour until failure is reached at approximately $90 \%$ of its yielding base shear, see Figure 13 . The ductility and base shear capacity of NB and CB are similar, however NB is more flexible. The higher ductility of WB can be related with the in-plan distribution of the bearing walls, being more regular.

For the seismic scenario considered, the greatest damage expected, as individual building in the direction orthogonal to the street, corresponds to $\mathrm{CB}$ (2.58) located on soil type $\mathrm{D}$, while the minor expected damage $(0.01)$ is obtained for the models NB and WB placed in soil type A. This behaviour is maintained for all soil types (see Table 7). The reason for these differences is attributed to the influence of the irregular configuration of the walls of $\mathrm{CB}$. The irregularity geometry and architecture of $\mathrm{CB}$ hinds the correct disposition of resisting elements and weakens the building. Furthermore, the damage increases with decreasing soil quality, the increase of the expected damage is very high in $\mathrm{CB}$, which goes from a state of non-damage, in hard 
ground, to a state of extensive damage in soft soils.

When the buildings are considered in soil type D damage is higher than in soil type A. As can be noticed from Figure 16, the fundamental period of vibration $\left(T_{1}\right)$ of all buildings falls in the range of maximum acceleration. Table 8 shows the spectral acceleration obtained for the fundamental periods of all buildings in $U_{y}$ direction and soils A and D.

With respect to MASS, in $X$-direction, no damage $\left(D_{M}=0.45\right)$ is expected if it is located in hard soil. However, expected damage increases from moderate to extensive as the soil stiffness decreases, being the $D_{M}=2.68$ for soil $\mathrm{D}$ and the probability for the extensive damage goes from $2 \%-46 \%$ and for collapse damage goes from $0 \%-14 \%$ for soils type A and D, respectively (Table 6). It is apparent that MASS is controlled by the seismic performance of the two CB's. Furthermore, the contribution of the interior buildings (NB and WB) is smaller since their longer walls are aligned in $Y$-direction; therefore, the increase in the overall mass is more important than their contribution to the resisting capacity.

\section{Conclusions}

Damage probability matrices obtained for $\mathrm{CB}, \mathrm{NB}, \mathrm{WB}$ and for a set of MASS located in the different types of soils of Barcelona predict the seismic damage.

The damage for MASS is larger than for the case of individual buildings NB, WB; however, it is similar for the CB. As isolated buildings, the most damaged building is the $\mathrm{CB}$, because of its irregular geometric characteristics.

The seismic acceleration considered of $0.04 \mathrm{~g}$ (NCSE-02 2002) corresponds to a basic intensity VI in the European Macroseismic Scale, EMS98, (Grünthal 1998). According to EMS98 and the calculated damage probability matrices it is observed that the probability of the expected damage is high. Moreover, the WB and NB located on 
soil type B suffer a mean damage degree of 0.26 and the average probabilities of damage are $14 \%$ for slight damage and $3 \%$ for moderate damage. Considering that the probability of $14 \%$ is on the border between the amounts considered as few and many buildings in the description of the damage degree VI in the EMS98 scale, then the WB and NB models are within the vulnerability class B of the EMS98 (Grünthal 1998).

The soil of the Eixample district is predominantly of type B, for this condition many MASS buildings suffer slight to extensive damage and some suffer collapse. Therefore, it is concluded that the UMB have high vulnerability to seismic acceleration considered in Barcelona (0.04g), which can be classified between Class A and Class B of the vulnerability classes characterized in the EMS98 scale.

The seismic assessment methodology used to evaluate the vulnerability, fragility and damage seismic estimation of UMB is a powerful method to apply in a low to moderate seismic zone.

The macroelement approach used in this research allows analysing the complex structural systems presented with reduced computational cost. However, this research could be extended in the future using other analytical techniques such as Discrete or Finite Element Methods. Other future trends include a parametric analysis considering different floor systems, brick types and to extend the study to other construction techniques in which pounding effect is expected.

\section{Acknowledgements}

This work has been sponsored by the support of the Spanish Ministry of Economy and Competitiveness through the research project BIA2012-36848, partially financed by the European Regional Development Fund (FEDER). The first author acknowledges the support of Prof. Lagomarsino and his research team (UNIGE) during a research stay supported by a Marie Curie Fellowship grant, and for the academic use 
3Muri software. The authors also acknowledge Mr. V. Alegre (COTCA, S.A.) for the information provided.

\section{References}

Alegre, V. (2002). "Informe sobre el estado actual de la estructura del edificios situado en la calle Bergara de Barcelona”. Barcelona, España: Informe Técnico de COTCA, S.A. [In Spanish], Barcelona, Spain.

ATC-40 (Applied Technology Council) (1996). "Seismic evaluation and retrofit of concrete buildings”. Federal Emergency Management Agency (FEMA). Seismic Safety Commission. Report: SSC 96-01. Vol. 1. Redwood City, California.

Bal, I.E., Crowley, H. and Pinho, R. (2008). "Displacement-based earthquakeloss assessment of Turkish masonry structures". Presented at the $14^{\text {th }}$ WCEE World Conference on Earthquake Engineering, Beijing, China, Oct12-17, paper 269: 8p.

Barbat, A.H., Pujades, L.G., Lantada, N. and Moreno, R. (2006). "Performance of Buildings under Earthquakes in Barcelona, Spain”. Comput-Aided Civil Infrastruct. Eng., 21(8), 573-593. doi:10.1111/j.1467-8667.2010.00660.x. Erratum: 2010, 25 (3): 226.

Betti, M. and Vignoli, A. (2008). "Modelling and analysis of a Romanesque church under earthquake loading: Assessment of seismic resistance”. Eng. Struct., 30(2), $352-367$.

Betti, M. and Vignoli, A. (2011). "Numerical assessment of the static and seismic behaviour of the basilica of Santa Maria all'Impruneta (Italy)". Constr. Build. Mater., 25(12), 4308-4324.

Brencich, A. and Lagomarsino, S. (1998). "A macroelement dynamic model for masonry shear walls". Computer methods in structural masonry-4, edited by G.N. Pande, J. Middleton and B. Kralj. 
Calvi, G. (1999). “A displacement-based approach for vulnerability evaluation of classes of buildings". J. Earthqu. Eng., 3(3), 411-438.

CEN (Comité Européen de Normalisation) Eurocode 8, EC-8. (2004). Design of structures for earthquake resistance - Part 1: General rules, seismic actions and rules for buildings. EN 1998-1:2004, CEN Brussels, Belgium, December, 229 p.

Cid, J., Susagna, T., Goula, X., Chavarria, L., Figueras, S., Fleta, J., Casas, A. and Roca, A. (2001). "Seismic zonation of Barcelona based on numerical simulation of site effects". Pure Appl. Geophys., 158, 2559-2577.

Faccioli, E. (2006). "Seismic hazard assessment for derivation of earthquake scenarios in Risk-UE”. Bull. Earthq. Eng., 4(4), 341-364.

Fajfar, P. (2000). “A nonlinear analysis method for performance bases seismic design". Earthq. Spectra, 16(3), 573-592.

Freeman, S.A. (1998). "Development and use of the capacity spectrum method". Presented at the $6^{\text {th }}$ US NCEE Conference on Earthquake Engineering, EERI, Seattle, May31-June4, paper 269: 12p.

Frumento, S., Giovinazzi, S., Lagomarsino, S. and Podestà, S. (2006). "Seismic retrofitting of unreinforced masonry buildings in Italy". Presented at the NZSEE New Zealand Society for Earthquake Engineering Conference, Napier, New Zealand, March10-12, paper 48: 8p.

Galasco, A., Lagomarsino, S. and Penna, A. (2002). “TREMURI Program: Seismic Analysis of 3D Masonry Buildings”. Program developed at Università degli Studi di Genova. Genoa, Italy.

Galasco, A., Lagomarsino, S., Penna, A. and Resemini, S. (2004). "Non-linear seismic analysis of masonry buildings". Presented at 13th World Conference on Earthquake Engineering (13WCEE), Vancouver, August 1-6, paper 843. 
Gambarotta, L. and Lagomarsino, S. (1993). "A microcrack damage model for brittle materials". Int. J. Solids Struct., 30, 177-98.

Gambarotta, L. and Lagomarsino, S. (1997). "Damage model for the seismic response of brick masonry shear walls. Part II: the continuum model and its applications”. Earthq. Eng. Struct. Dyn., 26(4), 423-439.

Grünthal, G., Ed. (1998). “European Macroseismic Scale (EMS98)”. Centre Européen de Géodynamique et Séismologie. Cahiers du Centre Europèen de Géodynamique et de Séismologie. Vol. 15. Luxemburg.

HAZUS 99-SR2. (2002). "Earthquake loss estimation methodology: user's manual, service release 2". Federal Emergency Management Agency (FEMA) \& National Institute of Building Sciences (NIBS). HAZUS Technical Manual. Volume 1-3. Washington, DC.

Lagomarsino, S. (2006). "On the vulnerability assessment of monumental buildings". Bull. Earthq. Eng, 4(4), 445-463. doi:10.1007/s10518-006-9025-y.

Lagomarsino, S., Galasco, A., Penna, A. and Cattari, S. (2008). "TREMURI: Seismic analysis program for 3DMasonry buildings". (User guide). Technical Report. Università degli Studi di Genova, Genoa, Italy.

Lungu, D., Aldea, A., Arion, A., Vacareana, R., Petrescu, F. and Cornea, T. (2001). "European distinctive features, inventory database and typology". Work Package 1 of RISK-UE Project. European Commission (contract: EVK4-CT-2000-00014).

Magenes, G., Kingsley, G.R., Calvi, G.M. (1995). "Static testing of a full scale, twostory masonry building: Test procedure and measured experimental response, in experimental and numerical investigation on a brick masonry building prototype”. Report 3.0 CNR-GNDT. Numerical Prediction of the experiment: 1.1-1.41.

Magenes, G. and Calvi, G.M. (1997). "In plane seismic response of brick masonry 
walls". Earthq. Eng. Struct. Dyn., 26(11), 1091-1112.

Mari, A., Alegre, V., Gens, A. and Roca, P. (2003). "Estudio preliminar sobre los posibles efectos de la construcción de un túnel para el tren de alta velocidad bajo los edificios situados entre las calles Mallorca, Valencia, Lepanto y Cartagena”. Technical Report. [In Spanish]. Departamento de Ingeniería de la Construcción. Universitat Politècnica de Catalunya. Barcelona, Spain.

Milutinovic, Z.V. and Trendafiloski, G.S. (2003). "Vulnerability of current buildings". Work Package 4 of the European RISK-UE Project Handbook: An advanced approach to earthquake risk scenarios with applications to different European towns. European Commission (contract: EVK4-CT-2000-00014).

Moreno, R. (2006). "Seismic risk assessment of buildings using nonlinear static analysis. Application to some seismic scenarios of Barcelona". [In Spanish]. Doctoral dissertation, Universitat Politècnica de Catalunya, Barcelona, Spain. Available at: http://hdl.handle.net/10803/6247.

Moreno-Gonzalez, R. and Bairan, J.M. (2013). "Seismic damage assessment for waffled-slabs reinforced concrete (RC) buildings in Barcelona". Int. J. Archit. Heritage, 7(1), 116-134. doi:10.1080/15583058.2011.616619.

Mouroux, P. and Le Brun, B. (2006). "Presentation of RISK-UE project". Bull. Earthq. Eng., 4(4), 323-339. doi:10.1007/s10518-006-9020-3.

NCSE-02 Normativa. (2002). Norma de Construcción Sismorresistente: Parte General y Edificación, Real Decreto 997/2002, Boletín Oficial del Estado: 244, Madrid.

Paricio, A. (2001). "Secrets d'un sistema constructiu: l'Eixample”. [In Catalan] Ed. UPC (Universitat Politecnica de Catalunya). Barcelona, Spain.

Penna, A. (2002). "A macro-element procedure for the non-linear dynamic analysis of masonry buildings". [In Italian]. Doctoral dissertation, Politécnico di Milano, 
Milan, Italy.

Penna, A., Cattari, S., Galasco, A. and Lagomarsino, S. (2009). "Seismic assessment of masonry structures by non-linear macro-element analysis". Presented at $2^{\text {nd }}$ Meeting of the South Australian Heritage Council, Keswick, U.K. April 3, paper 223.

Priestley, M.J.N., Calvi, G.M. and Kowalsky, M.J. (2007). "Displacement-based seismic design of structures”. IUSS Press. Pavia, Italy.

Punt d'Informació Cartogràfica de Barcelona. Escala 1/2000, Rosangel Moreno González, "http://www.bcn.cat/cgiguia/picclient?Servicio $=$ PICNET $\&$ Idioma $=0 \&$ Tipo $=$ PAR $\&$ Calle $=$ Valencia $\& N u m$ $\underline{\text { ero }=167 \& \text { Escala }=2000 \& \text { centrar } . x=1 \& \text { AntiAlias }=1 \& \text { filename }}$

Qaisar, A. and Akhtar, N. (2007). "Seismic resistance evaluation of unreinforced masonry buildings". J. Earthq. Eng., 11(2), 133-146. doi:10.1080/13632460601155638.

Shahzada, K., Khan, A.N., Elnashai, A.S., Ashraf, M., Javed, M., Naseer, A. and Alam, B. (2012). "Experimental seismic performance of unreinforced brick masonry buildings". Earthquake Spectra, 28(3), 1269-1290.

S.T.A. DATA (2013). "3muri General description Version 4". S.T.A. DATA srl, software informer, Italy, p. 78.

Tomazevic, M. (1999). "Earthquake-resistant design of masonry buildings". Imperial College Press, London.

Yépez, F. (1996). "Methodology for the assessment of the vulnerability and seismic risk of structures using simulation techniques". [In Spanish]. Doctoral dissertation, Universitat Politècnica de Catalunya, Barcelona, Spain.

Internet Source: 
$<$ http://www.bcn.cat/guia/bcnpicc.html> (Nov. 3, 2012, 10:22h).

$<$ https://maps.google.es/> (Nov. 5, 2012, 9:05h).

$<$ http://www.bcn.es/cgi_guia/picclient?Servicio=PICNET\&Idioma=0\&Tipo=UR

$\mathrm{B} \&$ Calle $=$ Villarroel $\&$ Numero $=138 \&$ Escala $=2000 \&$ AntiAlias $=1 \&$ filename $=>$ (Nov. 7, 2012). 


\section{Figures list}

Figure 1. Buildings distribution by age.

Figure 2. Elastic response spectra $(\mathrm{Sa}-\mathrm{T})$ used for Barcelona.

Figure 3. Main in-plane failure mechanism of masonry: (a) bending-rocking (flexural failure) and (b) shear-sliding failure.

Figure 4. Kinematic model for the macroelement.

Figure 5. Urban plan of the typical blocks of existing buildings in the Eixample district of Barcelona (reprinted from Punt d'Informació Cartogràfica de Barcelona)

Figure 6. Exterior façade (top-left), interior façade (top-right), floor plan (bottom-left) and axonometric perspective (bottom-right) typicals in the Eixample district (reprinted from Paricio 2001, with permission).

Figure 7. Steel column with sustentation beam (left) and timber floor (right).

Figure $8.3 \mathrm{D}$ view and highlights a side of a block comparable to the MASS analysed in the Eixample district and joints between adjacent buildings (bottom) [(a) Google Maps, (C) 2014 Google; (b) Imagery (C) 2014 Google, Google Map data, (C) 2014 Google, basado en BCN IGN España]

Figure 9. Plan, wall and model of CB.

Figure 10. Models of NB and WB and the corresponding main façade (macroelement).

Figure 11. Plan of interior buildings (NB and WB models).

Figure 12. View in plant of the three modes of vibration for NB: mode $1\left(U_{X}\right)$, mode 2 $(\theta)$ and mode $3\left(U_{Y}\right)$.

Figure 13. Capacity and bilinear curves of $\mathrm{CB}, \mathrm{NB}, \mathrm{WB}$ and MASS.

Figure 14. Fragility curves for CB, NB and WB (Y-direction).

Figure 15. Fragility curves for MASS ( $X$-direction).

Figure 16. Elastic response spectra with the fundamental period in $Y$-direction $(U y)$. 
Table 1. Response spectra parameters defined with the Eurocode 8.

\begin{tabular}{|ll|c|c|c|c|}
\hline & Parameters & Soil $\boldsymbol{A}$ & Soil $\boldsymbol{B}$ & Soil $\boldsymbol{C}$ & Soil $\boldsymbol{D}$ \\
\hline$S$ & soil parameter & 1.00 & 1.20 & 1.15 & 1.35 \\
\hline$T b(\mathrm{~s})$ & $\begin{array}{l}\text { define the initial limit of } \\
\text { the plateau of constant } \\
\text { acceleration }\end{array}$ & 0.15 & 0.15 & 0.20 & 0.20 \\
\hline$T c(\mathrm{~s})$ & $\begin{array}{l}\text { define the final limit of } \\
\text { the plateau of constant } \\
\text { acceleration }\end{array}$ & 0.40 & 0.50 & 0.60 & 0.80 \\
\hline$T d(\mathrm{~s})$ & $\begin{array}{l}\text { define the initiation of } \\
\text { the branch of constant } \\
\text { displacement }\end{array}$ & 2.00 & 2.00 & 2.00 & 2.00 \\
\hline$k_{1}$ & $\begin{array}{l}\text { define the shape of the } \\
\text { spectrum for periods of } \\
\text { vibration major that } T c\end{array}$ & 1.00 & 1.00 & 1.00 & 1.00 \\
\hline$k_{2}$ & $\begin{array}{l}\text { define the shape of the } \\
\text { spectrum for periods of } \\
\text { vibration major that } T d\end{array}$ & 2.00 & 2.00 & 2.00 & 2.00 \\
\hline
\end{tabular}


Table 2. Vibration natural period and MPF for CB, NB and WB.

\begin{tabular}{|l|c|c|c|c|}
\hline \multirow{2}{*}{ Models } & \multicolumn{2}{|c|}{ Period, $\mathbf{T}$ (s) } & \multicolumn{2}{c|}{ MPF $(\Gamma$ ) } \\
& $U_{Y}$ & $U_{X}$ & $\Gamma_{Y}$ & $\Gamma_{X}$ \\
\hline CB & $0.808-$ Mode 1 & $0.827-$ Mode 2 & 1.544 & 1.551 \\
\hline NB & $0.561-$ Mode 3 & $0.846-$ Mode 1 & 1.342 & 1.541 \\
\hline WB & $0.796-$ Mode 3 & $1.246-$ Mode 1 & 1.329 & 1.260 \\
\hline MASS & 0.659 & 0.818 & 1.407 & 1.451 \\
\hline
\end{tabular}


Table 3. Parameters of the bilinear capacity spectrum for UMB.

\begin{tabular}{|c|l|c|c|c|c|c|}
\hline \multicolumn{2}{|c|}{ Building models } & \multicolumn{2}{|c|}{ Yielding capacity } & \multicolumn{2}{c|}{ Ultimate capacity } & \multirow{2}{*}{ Ductility } \\
& $S d_{y}(\mathrm{~m})$ & $S a_{y}(\mathrm{~g})$ & $S d_{u}(\mathrm{~m})$ & $S a_{u}(\mathrm{~g})$ & $\mu$ \\
\hline \multirow{3}{*}{$Y$-direction } & $\mathrm{CB}$ & 0.011 & 0.116 & 0.051 & 0.124 & 4.64 \\
\cline { 3 - 7 } & $\mathrm{NB}$ & 0.015 & 0.189 & 0.071 & 0.198 & 4.73 \\
\cline { 2 - 7 } & WB & 0.025 & 0.115 & 0.168 & 0.104 & 6.72 \\
\hline$X$-direction & MASS & 0.013 & 0.0766 & 0.040 & 0.0908 & 3.08 \\
\hline
\end{tabular}


Table 4. Parameters of the fragility curves for UMB.

\begin{tabular}{|c|c|c|c|c|c|c|c|c|c|}
\hline \multirow{3}{*}{$\begin{array}{l}\text { Building } \\
\text { models }\end{array}$} & \multirow{3}{*}{$\begin{array}{l}\text { Analysis } \\
\text { direction }\end{array}$} & \multicolumn{8}{|c|}{ Damage states thresholds } \\
\hline & & \multicolumn{2}{|c|}{ Slight } & \multicolumn{2}{|c|}{ Moderate } & \multicolumn{2}{|c|}{ Extensive } & \multicolumn{2}{|c|}{ Collapse } \\
\hline & & $\begin{array}{l}\overline{S d_{1}} \\
(\mathrm{~m})\end{array}$ & $\beta_{1}$ & $\begin{array}{l}\overline{S d_{2}} \\
(\mathrm{~m})\end{array}$ & $\beta_{2}$ & $\begin{array}{l}\overline{S d_{3}} \\
(\mathrm{~m})\end{array}$ & $\beta_{3}$ & $\begin{array}{l}\mathrm{Sd}_{4} \\
(\mathrm{~m})\end{array}$ & $\beta_{4}$ \\
\hline $\mathrm{CB}$ & & 0.0077 & 0.29 & 0.0111 & 0.40 & 0.0210 & 0.61 & 0.0509 & 0.70 \\
\hline NB & $Y$-dir. & 0.0107 & 0.28 & 0.0153 & 0.39 & 0.0293 & 0.61 & 0.0712 & 0.70 \\
\hline WB & & 0.0177 & 0.28 & 0.0253 & 0.32 & 0.0609 & 0.67 & 0.1676 & 0.80 \\
\hline MASS & $X$-dir. & 0.0091 & 0.28 & 0.0130 & 0.34 & 0.0197 & 0.43 & 0.0400 & 0.55 \\
\hline
\end{tabular}


Table 5. Performance points for UMB, $S d P P(\mathrm{~cm})$.

\begin{tabular}{|l|l|c|c|c|c|}
\hline Models & Analysis & Soil $\boldsymbol{A}$ & Soil $\boldsymbol{B}$ & Soil $\boldsymbol{C}$ & Soil $\boldsymbol{D}$ \\
\hline $\mathrm{CB}$ & \multirow{3}{*}{$Y$-direction } & 0.61 & 0.91 & 1.05 & 2.15 \\
\cline { 4 - 6 } & & 0.56 & 0.84 & 1.03 & 2.15 \\
\cline { 3 - 6 } NB & 0.93 & 1.39 & 1.60 & 2.50 \\
\hline WB & \multirow{2}{*}{ M-direction } & 0.81 & 1.22 & 1.40 & 2.20 \\
\hline MASS & & &
\end{tabular}


Table 6. Damage probability matrices in (\%) for UMB.

\begin{tabular}{|c|c|c|c|c|c|c|c|}
\hline Soils & Analysis & Models & 0-No damage & 1-Slight & 2-Moderate & 3-Extensive & 4-Collapse \\
\hline \multirow{4}{*}{$\begin{array}{c}\text { Soil } \\
A\end{array}$} & \multirow{3}{*}{$Y$-direction } & $\mathrm{CB}$ & 79 & 14 & 5 & 2 & 0 \\
\hline & & NB & 99 & 1 & 0 & 0 & 0 \\
\hline & & WB & 99 & 1 & 0 & 0 & 0 \\
\hline & $X$-direction & MASS & 66 & 25 & 7 & 2 & 0 \\
\hline \multirow{4}{*}{$\begin{array}{c}\text { Soil } \\
B\end{array}$} & \multirow{3}{*}{$Y$-direction } & $\mathrm{CB}$ & 29 & 40 & 22 & 8 & 1 \\
\hline & & NB & 80 & 13 & 5 & 2 & 0 \\
\hline & & WB & 81 & 16 & 1 & 2 & 0 \\
\hline & $X$-direction & MASS & 15 & 42 & 29 & 12 & 2 \\
\hline \multirow{4}{*}{$\begin{array}{c}\text { Soil } \\
C\end{array}$} & \multirow{3}{*}{$Y$-direction } & $\mathrm{CB}$ & 15 & 42 & 31 & 11 & 1 \\
\hline & & NB & 54 & 3 & 11 & 5 & 0 \\
\hline & & WB & 64 & 28 & 5 & 3 & 0 \\
\hline & $X$-direction & MASS & 6 & 35 & 37 & 19 & 3 \\
\hline \multirow{4}{*}{$\begin{array}{c}\text { Soil } \\
D\end{array}$} & \multirow{3}{*}{$Y$-direction } & $\mathrm{CB}$ & 0 & 5 & 43 & 41 & 11 \\
\hline & & NB & 1 & 18 & 51 & 26 & 4 \\
\hline & & WB & 11 & 41 & 39 & 8 & 1 \\
\hline & $X$-direction & MASS & 0 & 6 & 34 & 46 & 14 \\
\hline
\end{tabular}


Table 7. Weight damage index values, $D_{M}$.

\begin{tabular}{|l|l|c|c|c|c|}
\hline $\begin{array}{l}\text { Building } \\
\text { models }\end{array}$ & $\begin{array}{l}\text { Analysis } \\
\text { direction }\end{array}$ & Soil $\boldsymbol{A}$ & Soil $\boldsymbol{B}$ & Soil $\boldsymbol{C}$ & Soil $\boldsymbol{D}$ \\
\hline CB & \multirow{3}{*}{ Y-dir. } & 0.30 & 1.12 & 1.41 & 2.58 \\
\cline { 3 - 6 } NB & & 0.01 & 0.29 & 0.67 & 2.14 \\
\cline { 3 - 6 } WB & 0.01 & 0.24 & 0.47 & 1.47 \\
\hline MASS & \multirow{2}{*}{ X-dir. } & 0.45 & 1.44 & 1.78 & 2.68 \\
\hline
\end{tabular}


Table 8. Spectral acceleration corresponding to $T_{1}$ (in $Y$-direction) for hard and soft soils.

\begin{tabular}{|l|c|c|c|}
\hline $\begin{array}{l}\text { Building } \\
\text { models }\end{array}$ & $\boldsymbol{T}_{\mathbf{1}}(\mathbf{s})$ & Sa(g) Hard soil $(\boldsymbol{A})$ & Sa(g) Soft soil (D) \\
\hline CB & 0.808 & 0.0495 & 0.134 \\
\hline NB & 0.561 & 0.0713 & 0.135 \\
\hline WB & 0.796 & 0.0502 & 0.135 \\
\hline
\end{tabular}




\section{Performance of existing modernist buildings in Barcelona}

\section{Figures list}

Figure 1. Buildings distribution by age.

Figure 2. Elastic response spectra $(S a-T)$ used for Barcelona.

Figure 3. Main in-plane failure mechanism of masonry: (a) bending-rocking (flexural failure) and (b) shear-sliding failure.

Figure 4. Kinematic model for the macroelement.

Figure 5. Urban plan of the typical blocks of existing buildings in the Eixample district of Barcelona (Internet source).

Figure 6. Exterior façade (top-left), interior façade (top-right), floor plan (bottom-left) and axonometric perspective* (bottom-right) typicals in the Eixample district. Note:*Paricio (2001).

Figure 7. Steel column with sustentation beam (left) and timber floor (right).

Figure 8. 3D view and highlights a side of the block comparable to the MASS analysed in the Eixample district (Internet source).

Figure 9. MASS: $C B_{1}+N B_{1}+W B_{1}+N B_{2}+W B_{2}+N B_{3}+C B_{2}$, disposition of the buildings.

Figure 10. Plan, wall and model of CB.

Figure 11. Models of NB and WB and the corresponding main façade (macroelement).

Figure 12. Plan of interior buildings (NB and WB models).

Figure 13. Capacity and bilinear curves of $\mathrm{CB}, \mathrm{NB}, \mathrm{WB}$ and MASS.

Figure 14. Fragility curves for CB, NB and WB ( $Y$-direction).

Figure 15. Fragility curves for MASS ( $X$-direction).

\footnotetext{
${ }^{1} \mathrm{PhD}$. Civil Engineer, Researcher, (Corresponding author). E-mail: mgrosangel@ciccp.es

${ }^{2} \mathrm{PhD}$. Civil Engineer, Assoc. Professor. E-mail: jesus.miguel.bairan@upc.edu

Dept. of Construction Engineering, Universitat Politecnica de Catalunya, Campus

Nord, C/Jordi Girona 1-3, Mod. C-1, 201-b, 08034, Barcelona, Spain.
} 


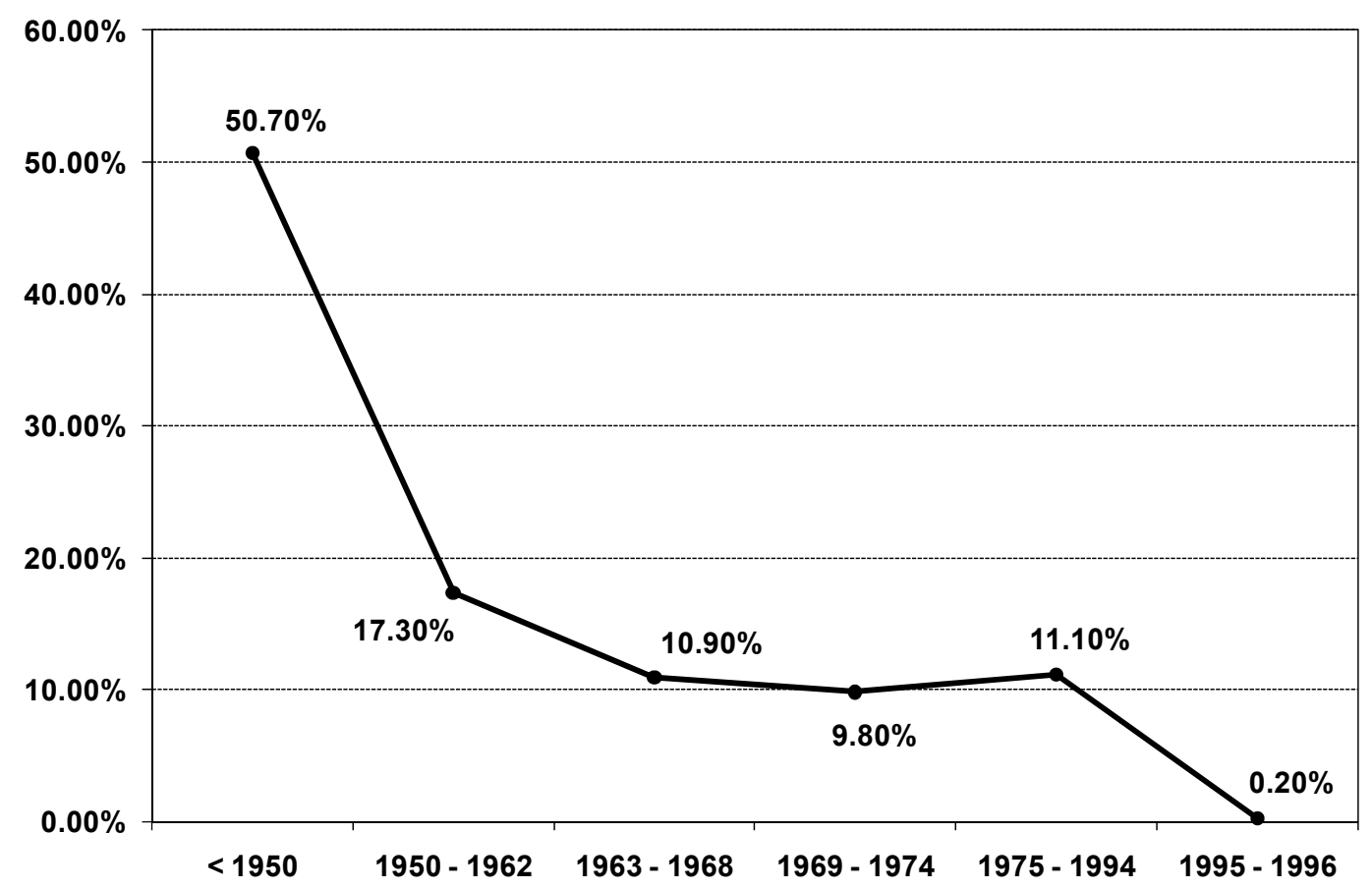

Figure 1. Buildings distribution by age. 


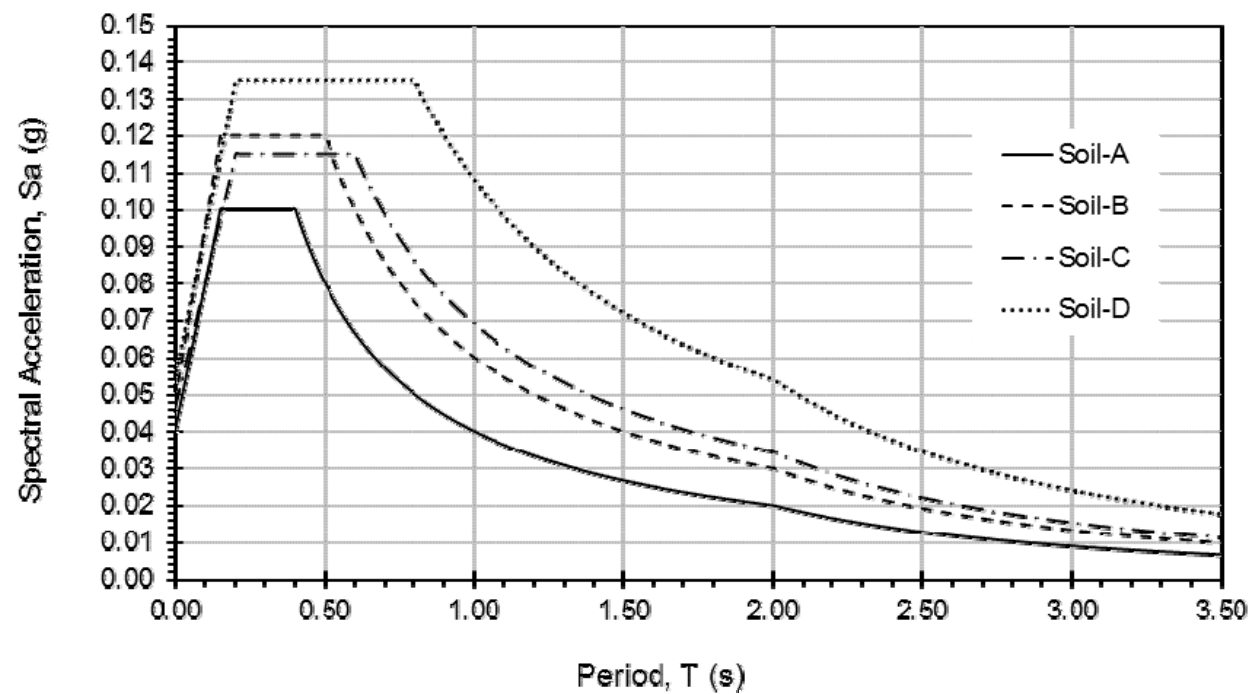

Figure 2. Elastic response spectra $(\mathrm{Sa}-\mathrm{T})$ used for Barcelona. 
(a)

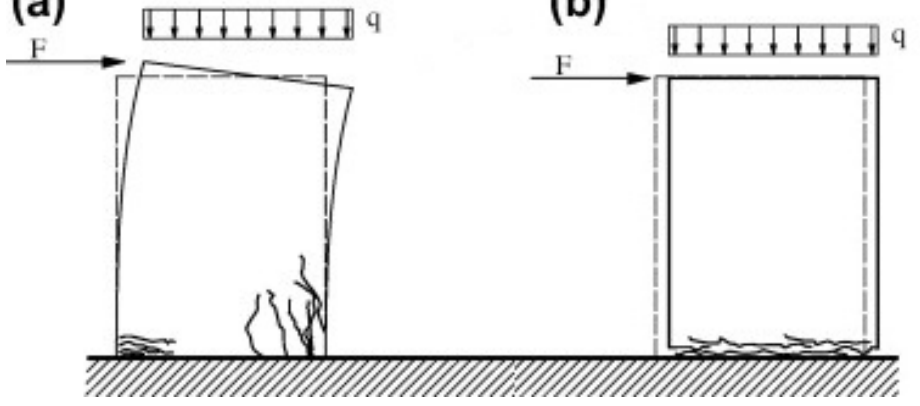

Figure 3. Main in-plane failure mechanism of masonry: (a) bending-rocking (flexural failure) and (b) shear-sliding failure. 

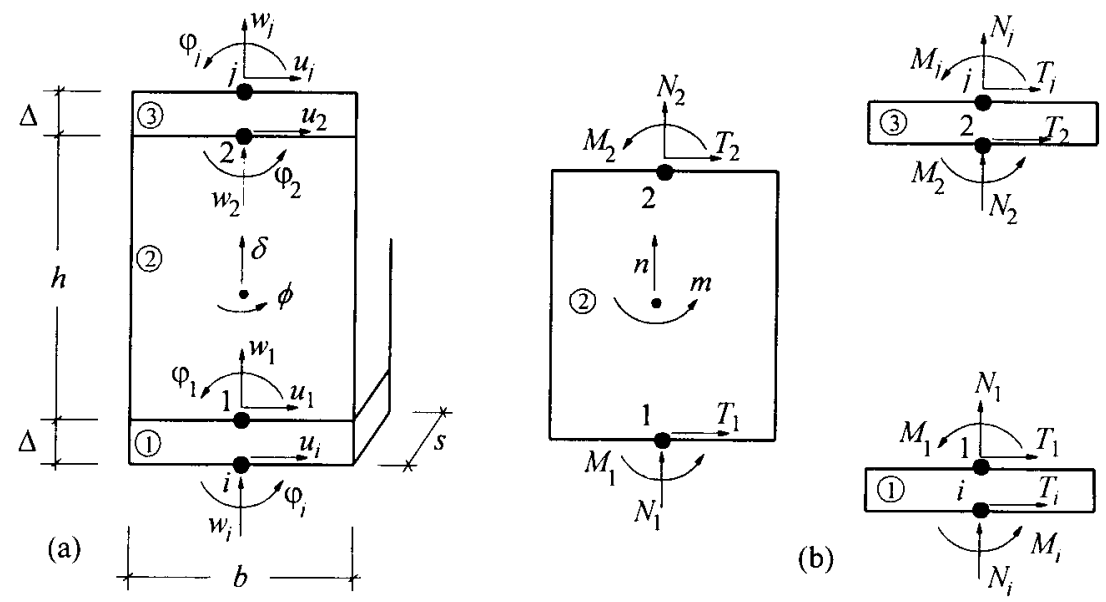

Figure 4. Kinematic model for the macroelement. 


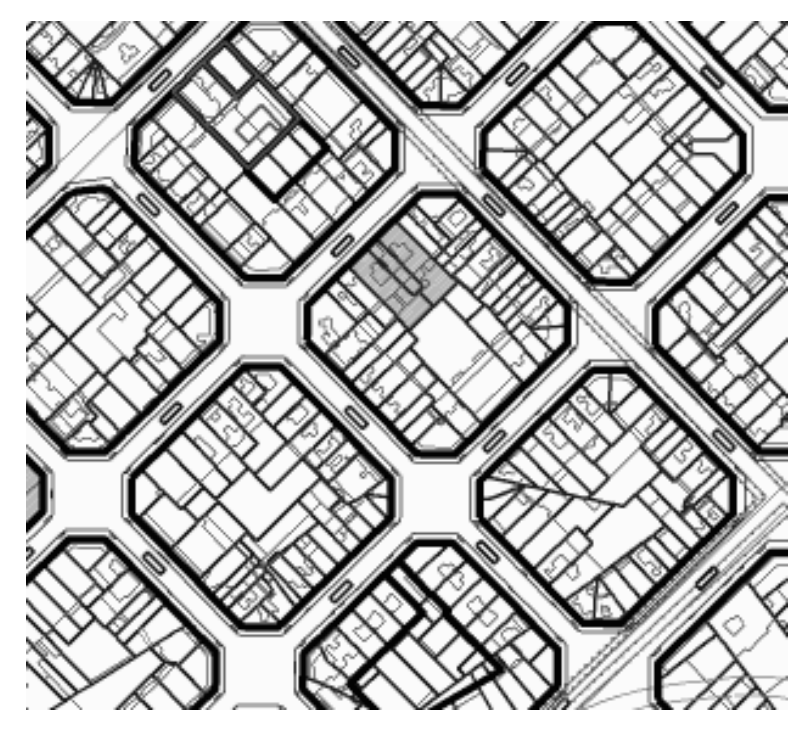

Figure 5. Urban plan of the typical blocks of existing buildings in the Eixample district of Barcelona (Internet source). 

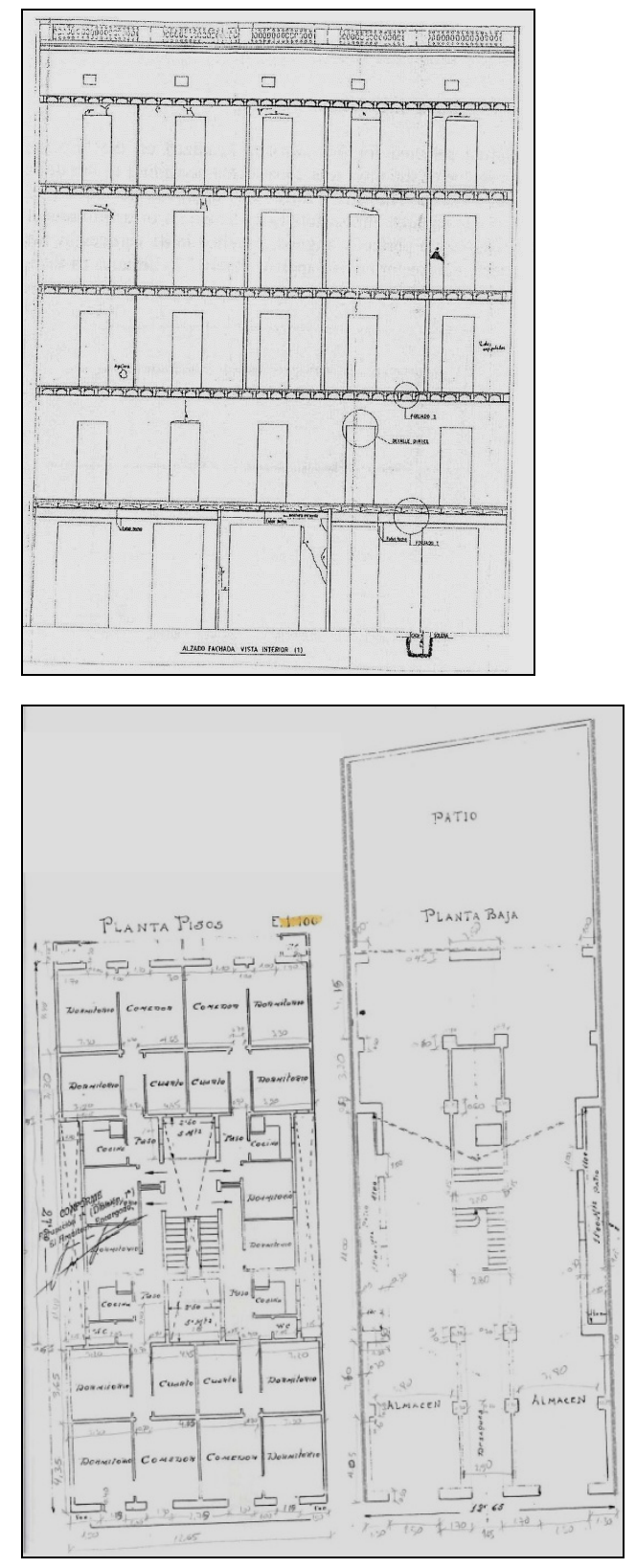
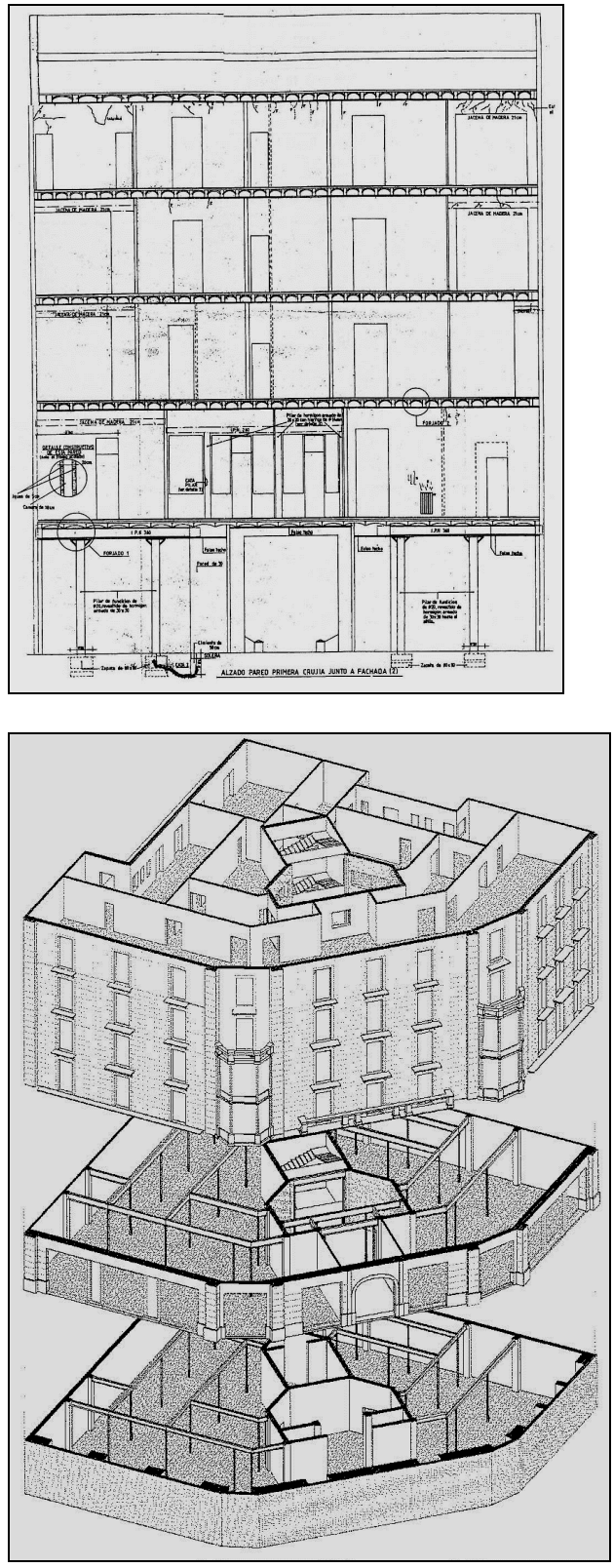

Figure 6. Exterior façade (top-left), interior façade (top-right), floor plan (bottom-left) and axonometric perspective* (bottom-right) typical in the Eixample district. Note:*Paricio (2001) 


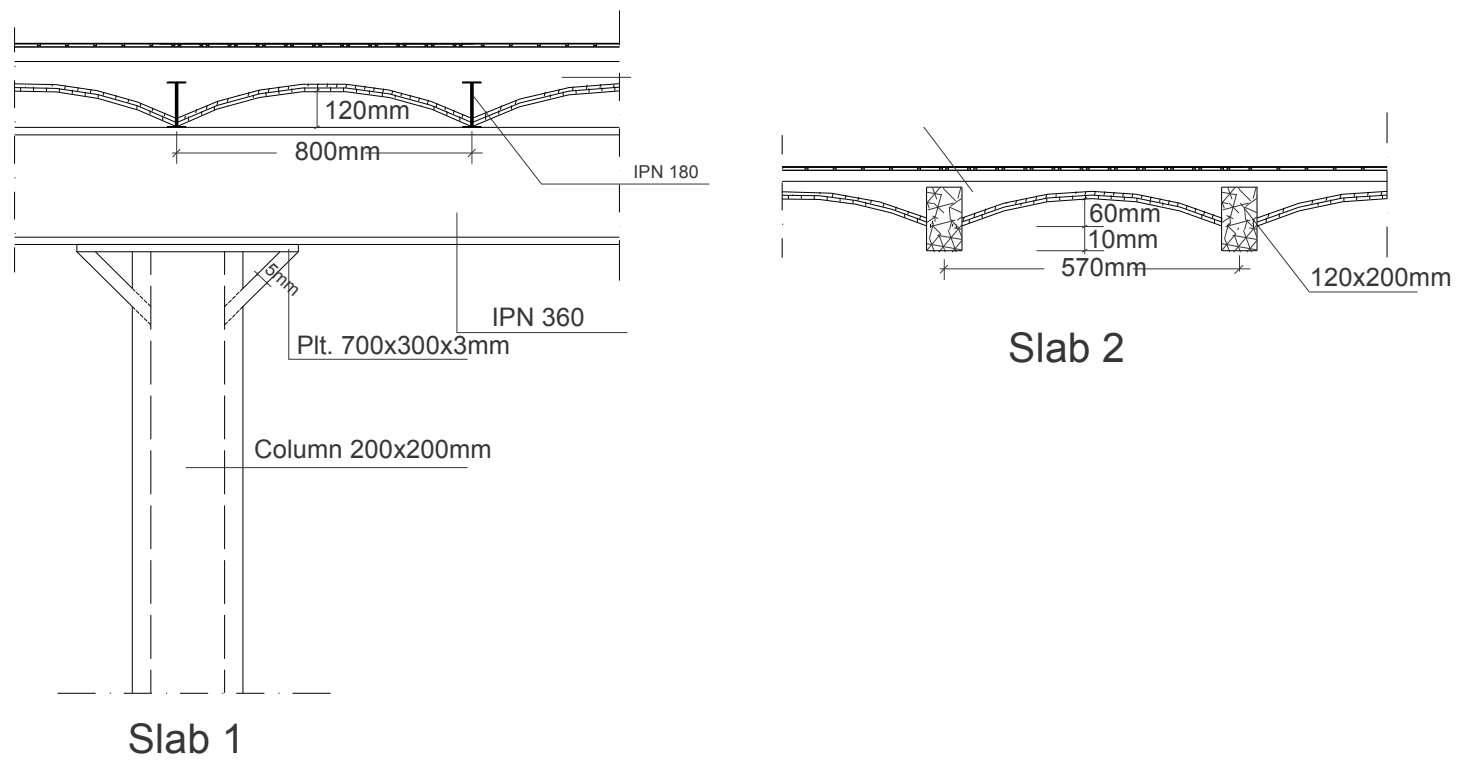

Figure 7. Steel column with sustentation beam (left) and timber floor (right). 

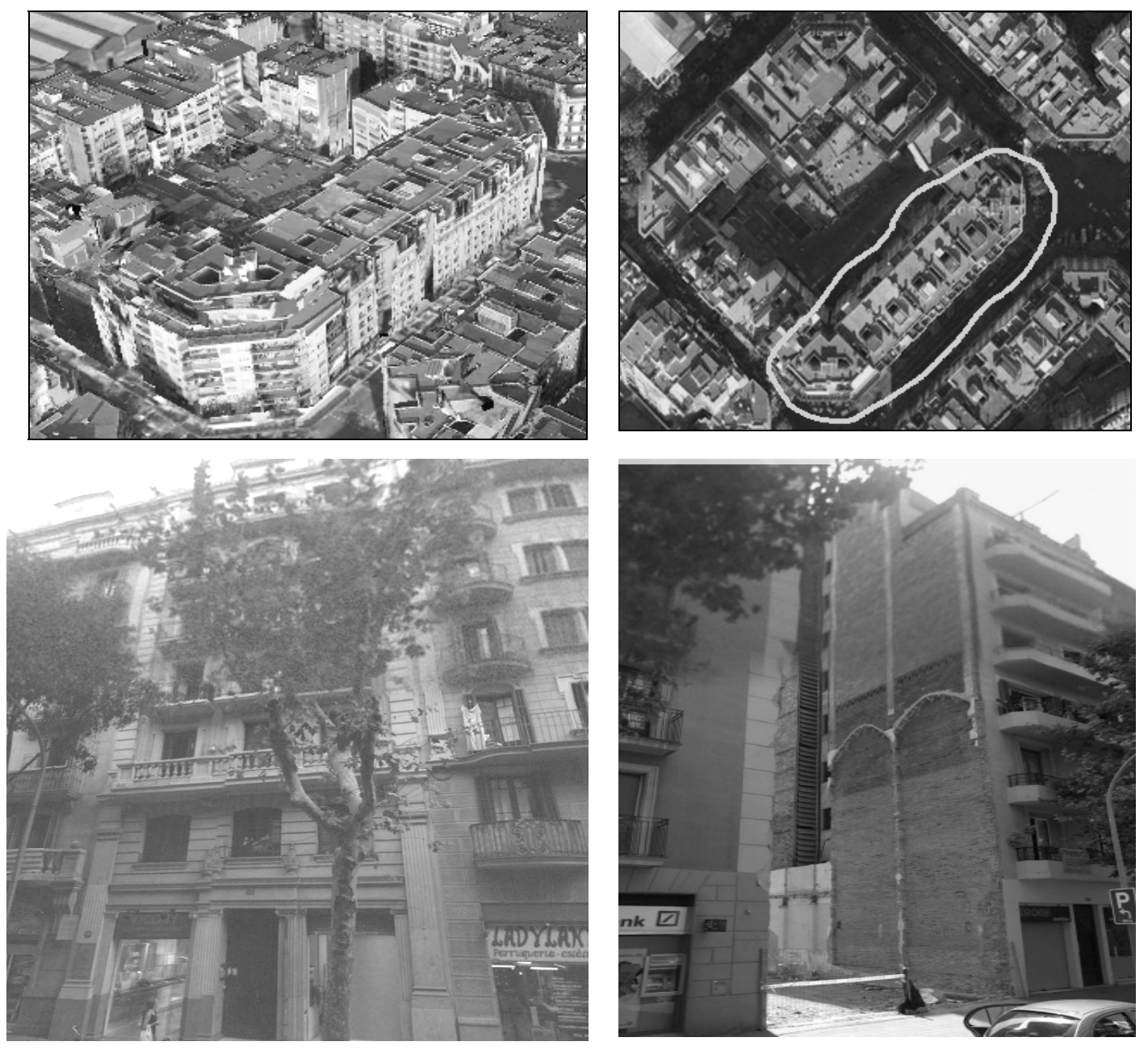

Figure 8. 3D view and highlights a side of a block comparable to the MASS $\left(C B_{1}+N B_{1}+W B_{1}+N B_{2}+W B_{2}+N B_{3}+C B_{2}\right)$ analyzed in the Eixample district (Internet source) and joints between adjacent buildings (bottom). 

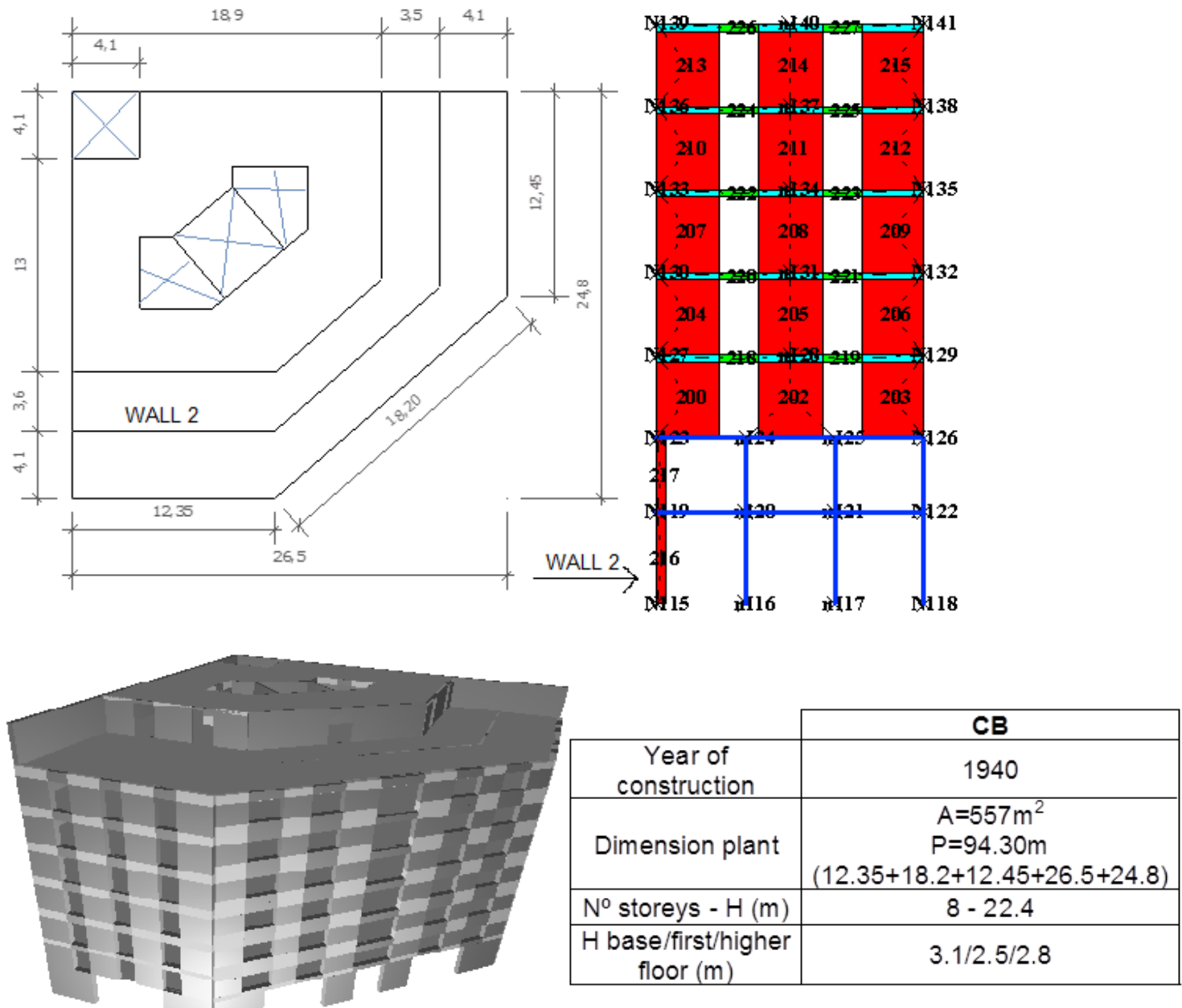

Figure 9. Plan, wall and model of CB. 


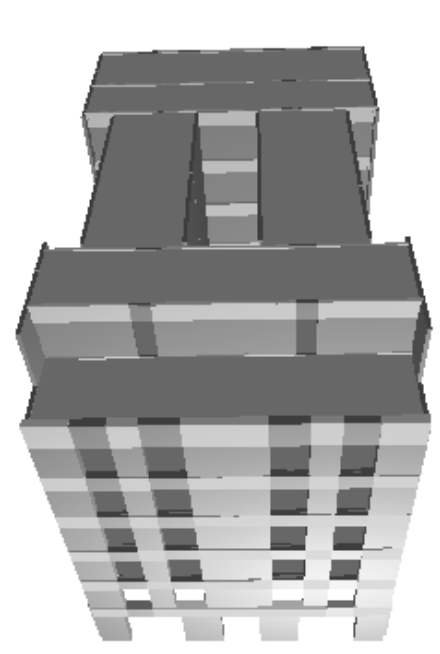

FAÇADE

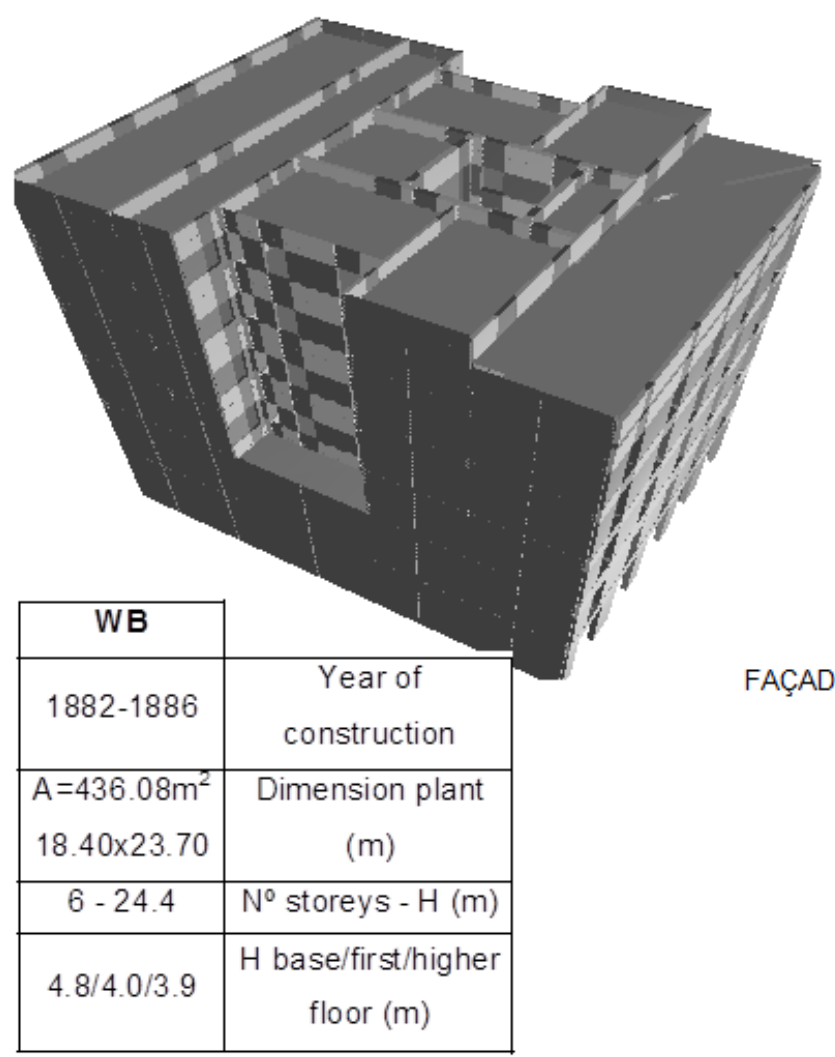

\begin{tabular}{|c|c|}
\cline { 2 - 2 } \multicolumn{1}{c|}{} & NB \\
\hline $\begin{array}{c}\text { Year of } \\
\text { construction }\end{array}$ & $1930-1931$ \\
\hline $\begin{array}{c}\text { Dimension plant } \\
(\mathrm{m})\end{array}$ & $\begin{array}{c}\mathrm{A}=341.55 \mathrm{~m}^{2} \\
12.65 \times 27.00\end{array}$ \\
\hline $\begin{array}{c}\mathrm{N}^{0} \text { storeys }-\mathrm{H}(\mathrm{m}) \\
\mathrm{H} \text { base/first/higher } \\
\text { floor }(\mathrm{m})\end{array}$ & $4.0 / 3.0 / 3.0$ \\
\hline
\end{tabular}

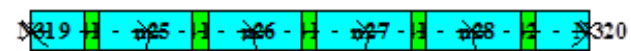

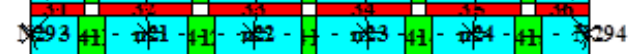

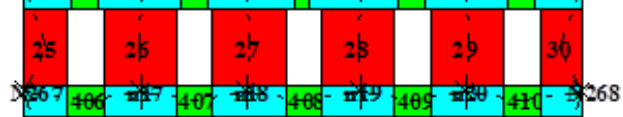

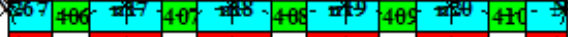

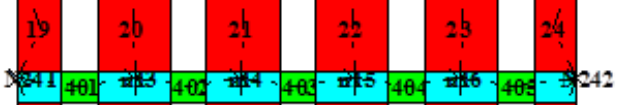

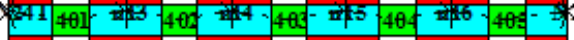

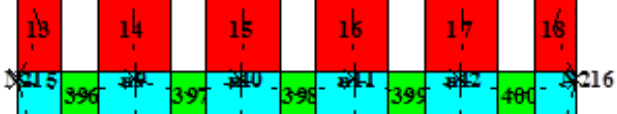

X AÇADE $\sum_{203} \quad \begin{gathered}21 \\ 1 \\ j\end{gathered}$

Figure 10. Models of NB and WB and the corresponding main façade (macroelement). 


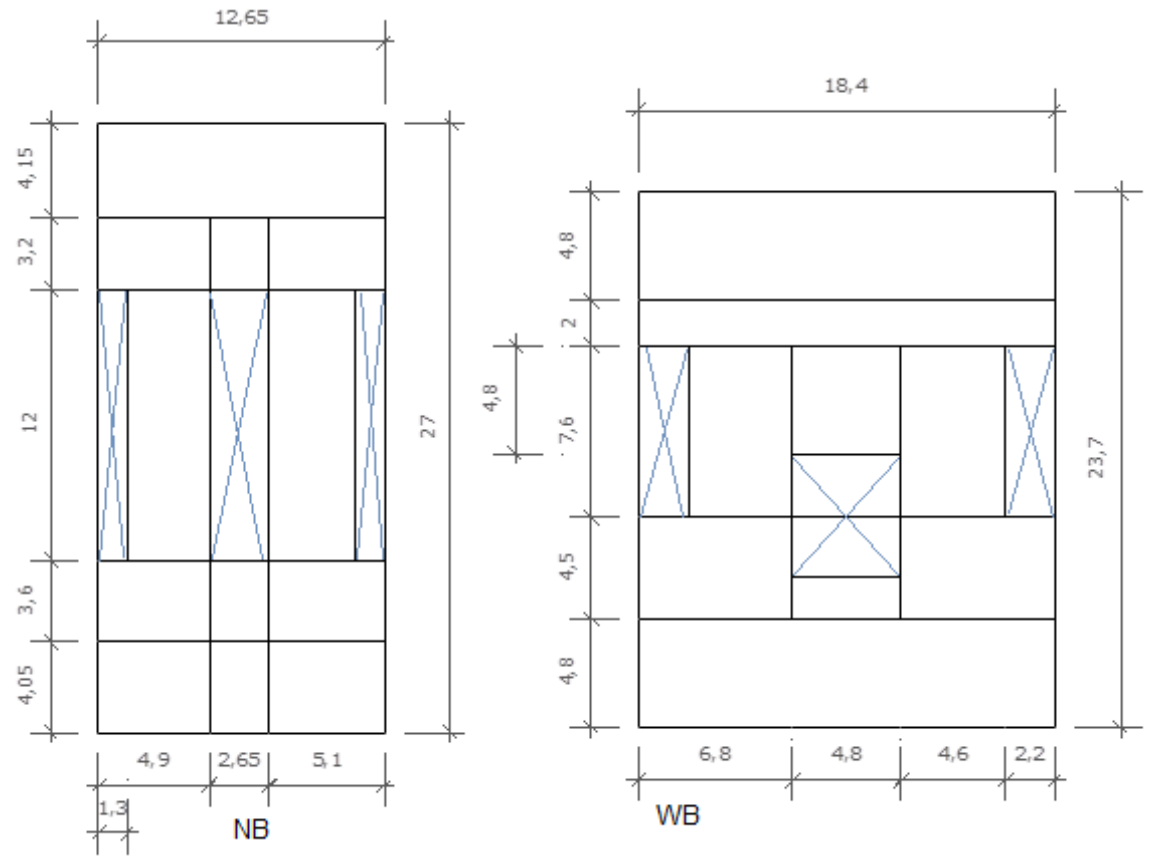

Figure 11. Plan of interior buildings (NB and WB models). 


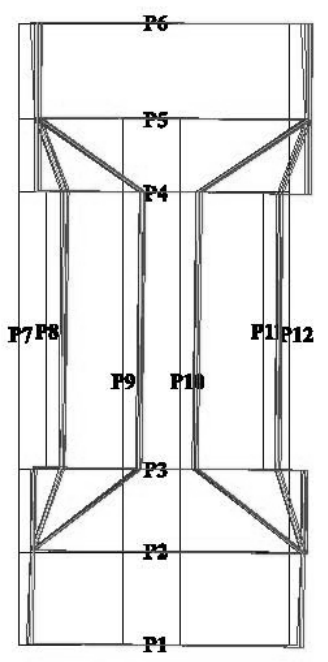

Modo 1

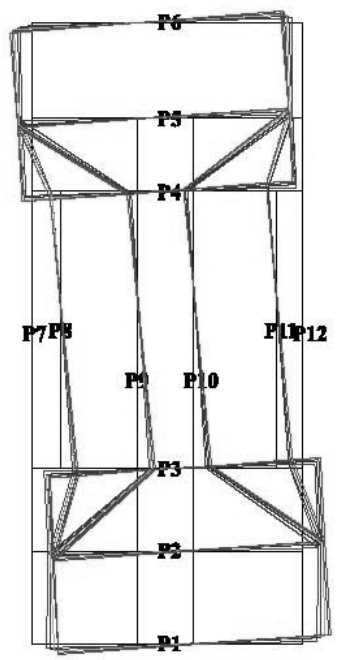

Modo 2

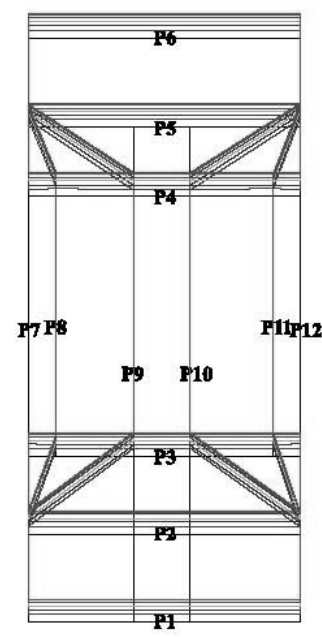

Modo 3

Figure 12. View in plant of the three modes of vibration for NB: mode $1\left(U_{X}\right)$, mode 2 $(\theta)$ and mode $3\left(U_{Y}\right)$. 


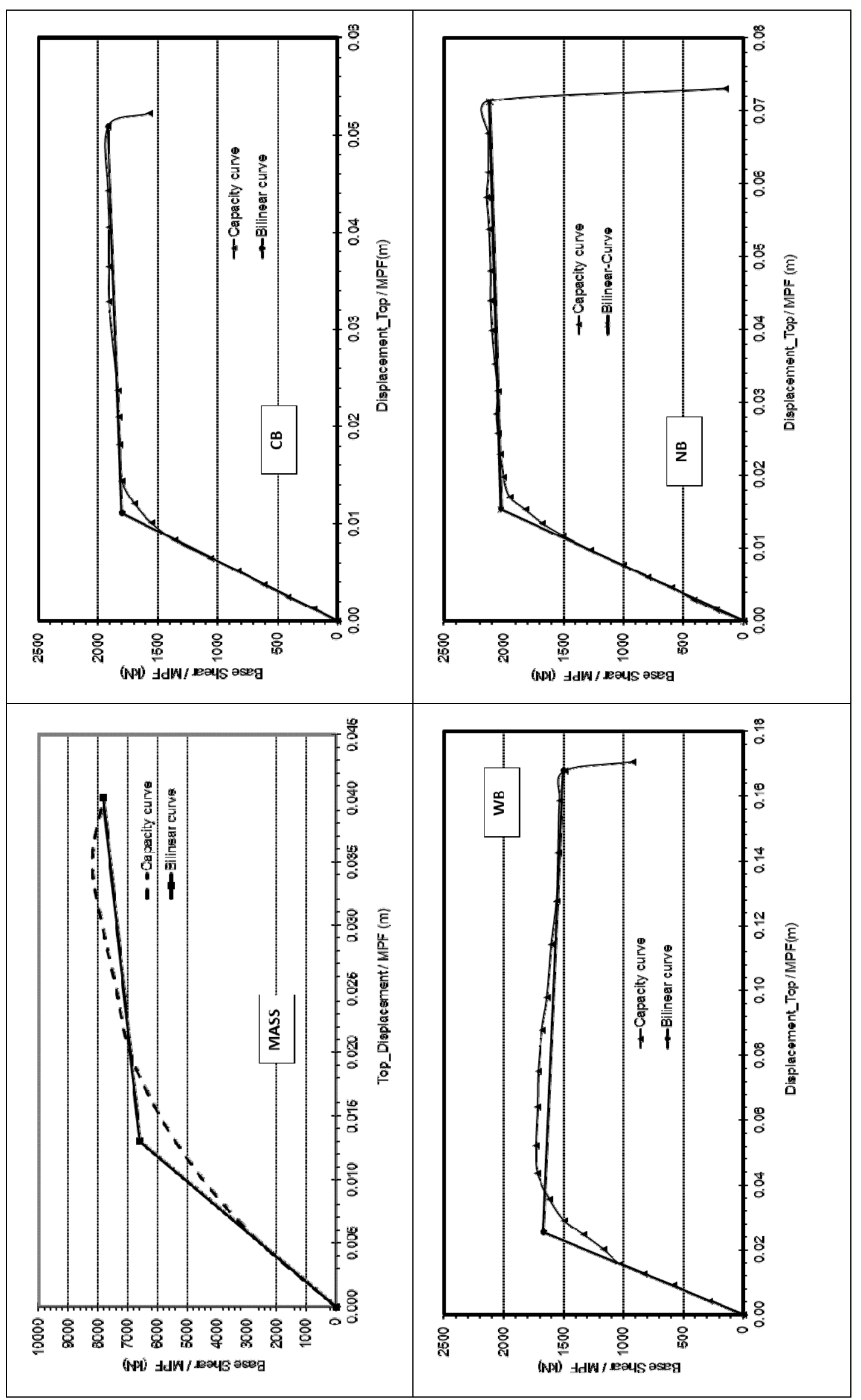

Figure 13. Capacity and bilinear curves of $\mathrm{CB}, \mathrm{NB}, \mathrm{WB}$ and MASS. 


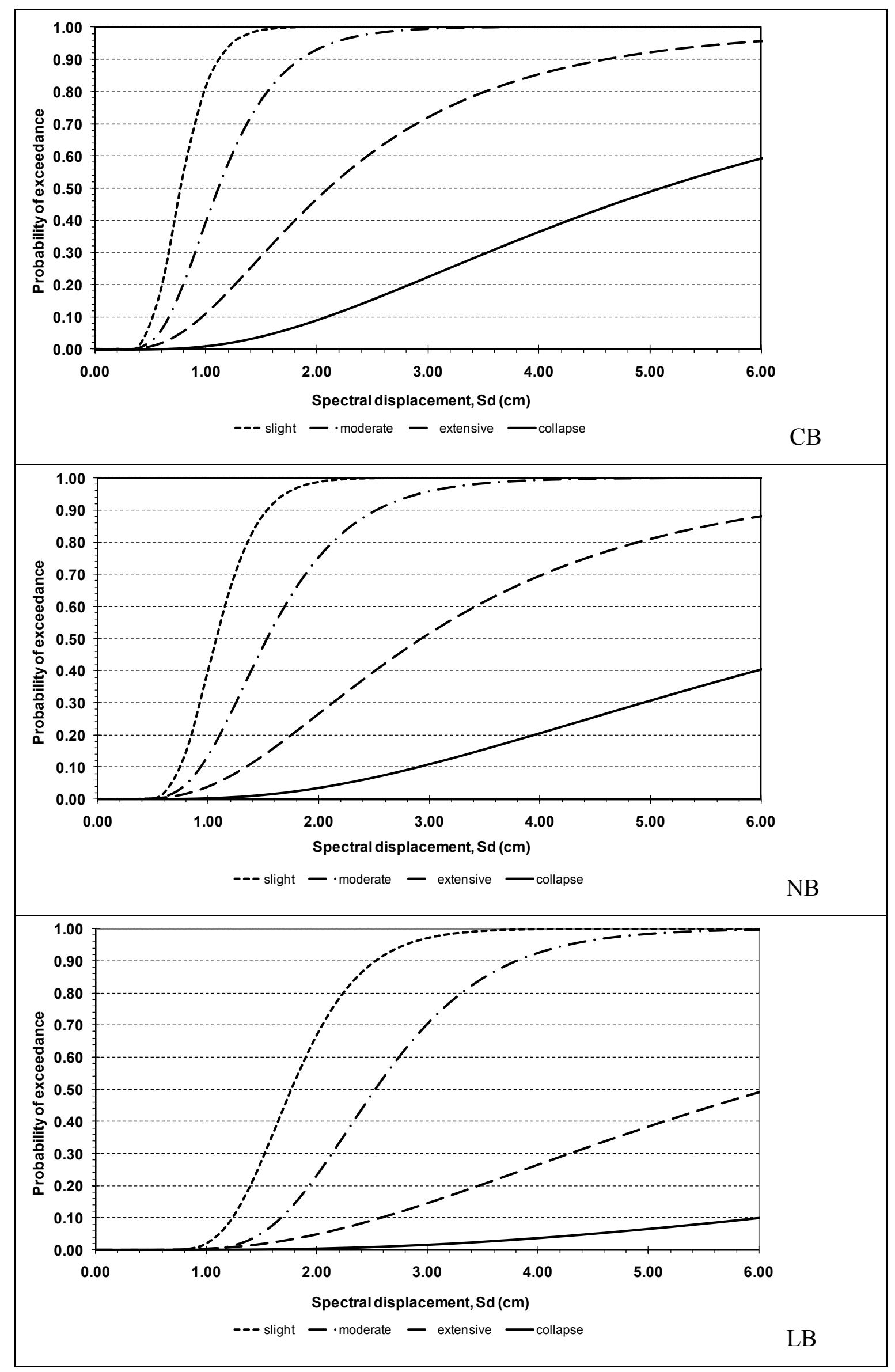


Figure 14 . Fragility curves for $\mathrm{CB}, \mathrm{NB}$ and WB ( $Y$-direction).

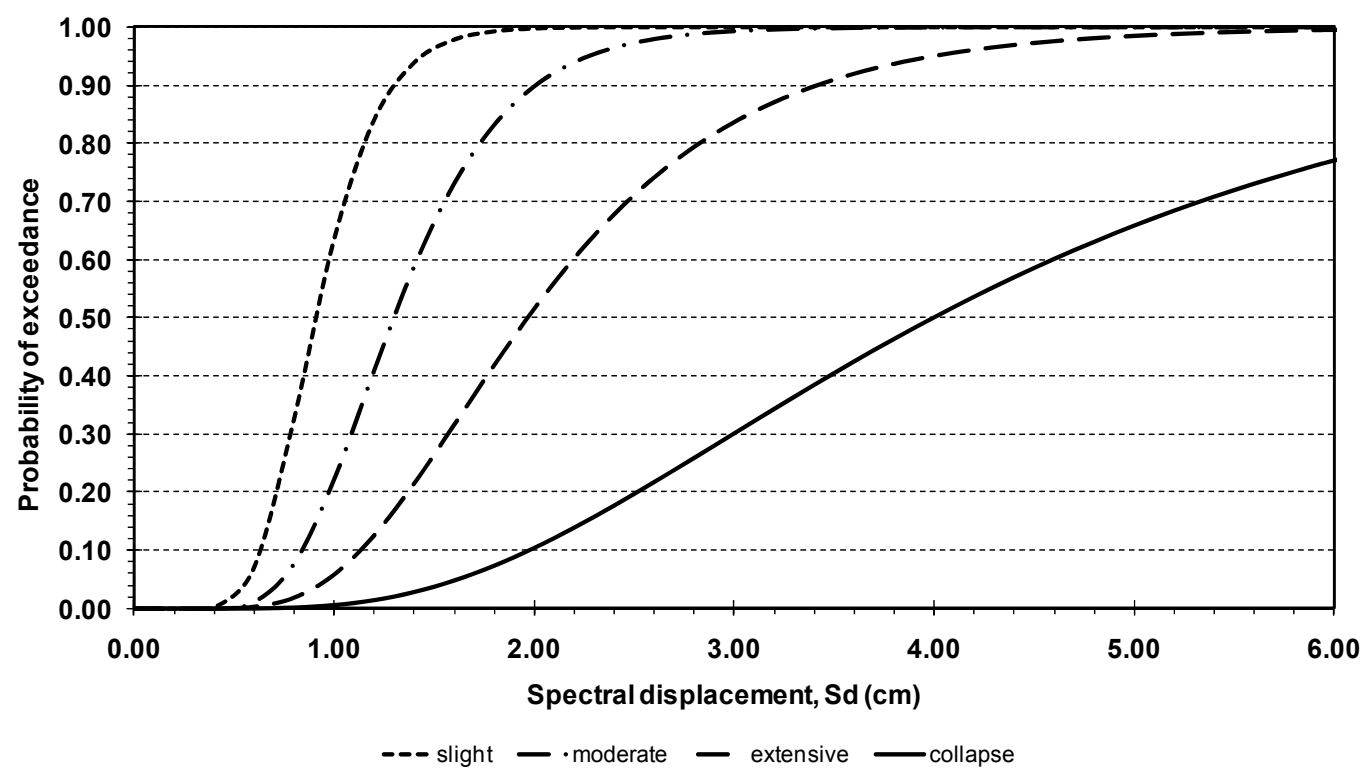

Figure 15 . Fragility curves for MASS ( $X$-direction). 


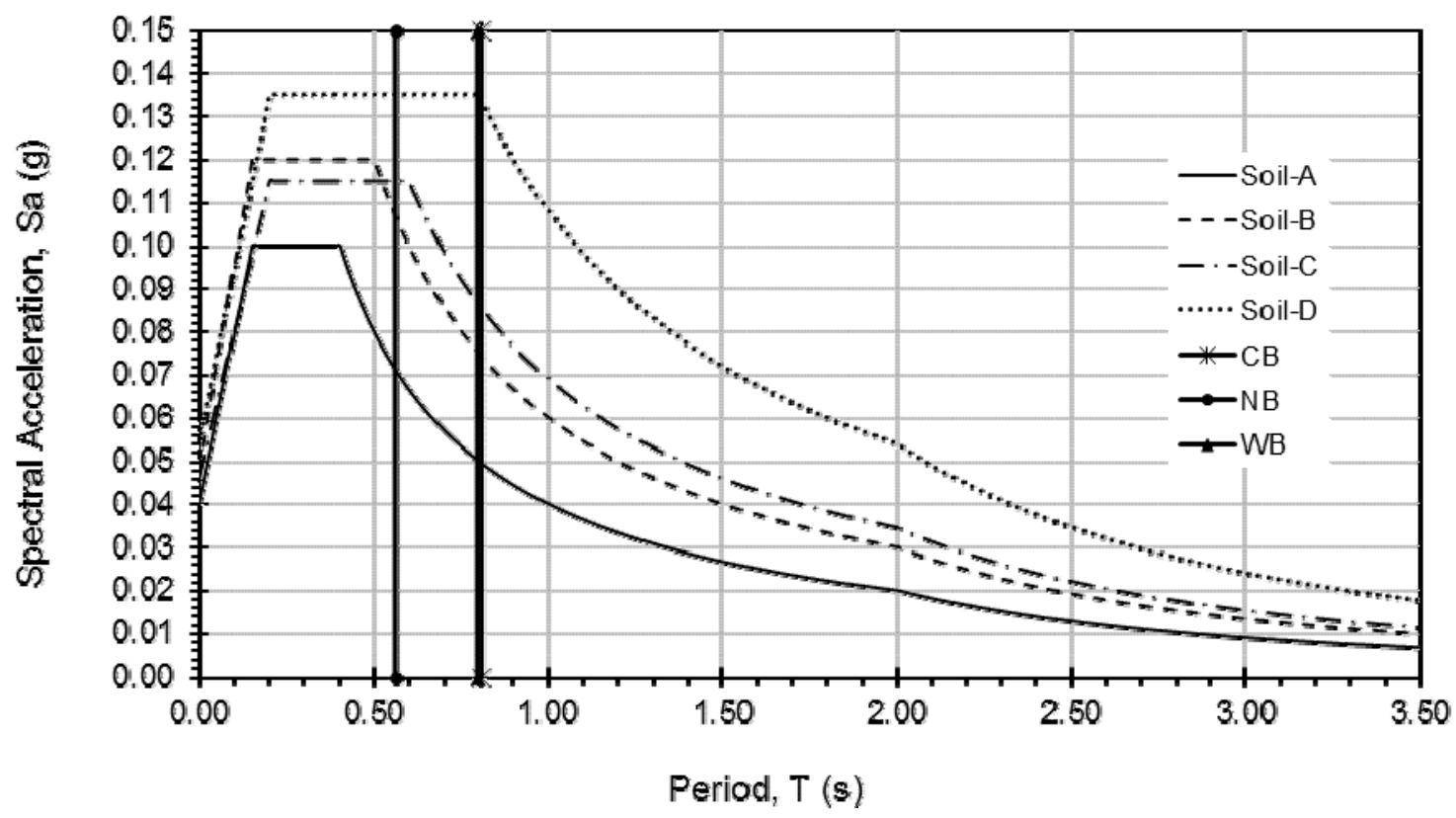

Figure 16. Elastic response spectra with the fundamental period in $Y$-direction $(U y)$. 